\title{
The Smicronychini of southern Africa (Coleoptera, Curculionidae): Review of the tribe and description of 12 new species
}

\author{
Julien M. HARAN \\ CBGP, CIRAD, Montpellier SupAgro, INRA, IRD, Univ. Montpellier, Montpellier, France. \\ Email: julien.haran@cirad.fr \\ (ㄱttps://orcid.org/0000-0001-9458-3785 \\ urn:1sid:zoobank.org:author:A04E1722-994A-44AD-8FD2-28DC0F220805
}

\begin{abstract}
This study reviews the species of the tribe Smicronychini Seidlitz, 1891 found in southern Africa. In total, 18 species are recognized in this region, 12 of them being described as new (Sharpia madibai sp. nov., Afrosmicronyx cycnii sp. nov., A. louwi sp. nov., A. marshalli sp. nov., A. nebulosipennis sp. nov., Smicronyx pseudocoecus sp. nov., S. australis sp. nov., S. drakensbergensis sp. nov., S. gracilipes sp. nov., S. paucisquamis sp. nov., S. san sp. nov., S. similis sp. nov.). The following genera and species are newly reported from this area: Afrosmicronyx Hustache, 1935; Sharpia Tournier, 1873; Smicronyx pauperculus Wollaston, 1864; S. albosquamosus Wollaston, 1854 and S. namibicus Haran, 2018. New host plant taxa and plant associations for the tribe are reported among the families Gentianaceae Juss., Orobanchaceae Vent. and Convolvulaceae Juss. A key to species and images of the habitus of adults and male genitalia are provided.
\end{abstract}

Keywords. Sharpia, Smicronyx, Afrosmicronyx, new species, biological control.

Haran J.M. 2021. The Smicronychini of southern Africa (Coleoptera, Curculionidae): Review of the tribe and description of 12 new species. European Journal of Taxonomy 735: 34-73.

https://doi.org/10.5852/ejt.2021.735.1239

\section{Introduction}

The weevil fauna of southern African is still unevenly known (Proches 2003). While large-bodied groups have received attention from early and more recent authors (i.e., Marshall 1946; Louw 1995), the smaller-bodied groups (Borovec \& Skuhrovec 2018), in particular among the subfamily Curculioninae Latreille, 1802, have scarcely been studied (but see Caldara et al. 2009). As a result, the few taxonomic revisions of genera conducted in the smaller-bodied clades usually lead to the discovery of a large number of new species (Caldara 1989, 1996). Following the revisions of several genera among the Afrotropical Smicronychini Seidlitz, 1891 (Haran \& Perrin 2017; Haran 2018) the diversity of this tribe from southern Africa was explored.

Very little was known about the Smicronychini from the southern African region (here considered below the $20^{\text {th }}$ parallel South). An initial species, Smicronyx fallax (Gyllenhal,1836) was described from "Caffraria", an area currently including broadly the Eastern Cape Province of the Republic of South 
Africa. More recently, a second species distributed at several places within tropical Africa (S. zonatus Haran, 2018) was described based on specimens from the Western Cape Province of the Republic of South Africa. Lastly, in recent years, attempts were made to introduce S. lutulentus Dietz, 1894 from North America to South Africa for biological control of the Asteraceous weed Parthenium hysterophorus Linnaeus, 1753 (Strathie et al. 2011).

Knowledge on the diversity of Smicronychini in southern Africa is needed to ensure that native and introduced species can be effectively distinguished, especially when the establishment of introduced species is tracked based on field sampling. Due to their associations with parasitic and hemi-parasitic plants of crops in the Afrotropical region (genera Orobanche Linnaeus, 1753, Cuscuta Linnaeus, 1753, Striga Loureiro, 1790, Buchnera Linnaeus, 1753) the genera of this tribe are of potential interest for biocontrol. The aim of this study was therefore to revise the Smicronychini of southern Africa. About 400 specimens obtained from Natural History Museums and newly collected ones were examined using a standard taxonomic approach based on morphology and molecular diagnostic tools. A key, a description or a diagnosis of each species is provided with images of the habitus of adults and penis of males.

\section{Material and Methods}

\section{Abbreviations of depositories}

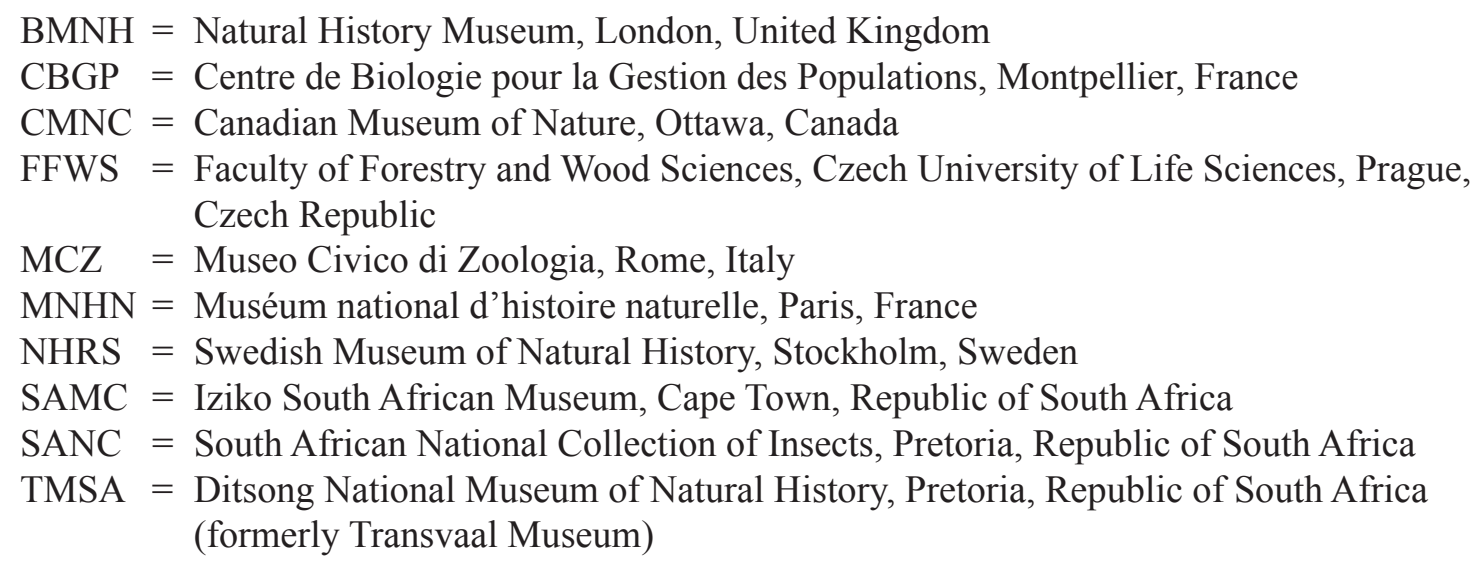

\section{Preparation and photographs}

The abdomens of adult specimens were extracted and digested in $\mathrm{KOH}$ to obtain clean preparations of genital structures, as these are commonly used to distinguish between species in Smicronychini (Zumpt 1936; Péricart 1957; Haran et al. 2017; Haran \& Perrin 2017; Haran 2018). The illustration of male structures was restricted to the body of the penis, as it shows substantial variation between species of Smicronyx. The endophallic structures of male genitalia and external genitalia of the female (spermatheca and sternum VIII) are not described or illustrated, as examination of these structures did not reveal any significant or phylogenetically informative differences between most of the species from the area examined. The habitus and male genitalia were photographed using a Keyence ${ }^{\circ}$ VHX5000 imaging system. Extended depth-of-field images were obtained using the software of the imaging station. Measurements were taken with an optical micrometer. Body length refers to the distance from the apical margin of the head (excluding the rostrum) to the apex of the elytra. Rostrum length refers to the distance between the apical margin of the eyes and the apex of mandibles. The ratio of width to length (w/l) was measured at the widest point of the prothorax, the elytra and the penis. The length of the elytra was measured between the anterior part of the scutellum and the apex of the elytra. The length of the penis was measured between the base of the penis body (apodemes excluded) and the apex. The terminology used follows Lyal (2019). Scales are important features for distinguishing between Smicronyx species, but they are fragile and may be partly lacking on some individuals. The diagnoses 
and descriptions in this study refer to fresh specimens with an entire vestiture. The identity of the species described before recent revisions was established using the original description ( $S$. fallax and S. lutulentus), or examination of type material and reference collections (S. albosquamosus Wollaston, 1854 and $S$. pauperculus Wollaston, 1864). Neotype designation follows ICZN (1999) article 75. Data on each label of holotypes are reported between single quotation marks, each line of the label is separated by a slash, additional information to help label interpretation is given in square brackets.

\section{Molecular analysis}

A specimen per species was sequenced for the standard barcode fragment when fresh material could be obtained. DNA was extracted from entire specimens using a DNeasy Blood \& Tissue kit (Qiagen, Hilden, Germany). PCR amplifications were carried out using the standard primers for barcoding (mitochondrial cytochrome c oxidase subunit I, COI) for invertebrates: LCO1490: 5'-GGTCAACAAATCATAAAGATATTGG-3' and HCO2198: 5'-TAAACTTCAGGGTGACCAAAAAATCA-3' (Folmer et al. 1994). PCR reactions were carried out on a Mastercycler ${ }^{\circledR}$ Nexus (Eppendorf, Hamburg, Germany) in a volume of $10 \mu \mathrm{l}$ of PCR mix containing $5 \mu \mathrm{l}$ of Multiplex Master Mix (Qiagen, Hilden, Germany), $0.8 \mu \mathrm{l}$ of primers (Forward and Reverse at $2 \mu \mathrm{M})$ and $2 \mu \mathrm{l}$ of DNA. The PCR conditions were as follows: initial DNA denaturation at $94^{\circ} \mathrm{C}$ for 15 minutes, followed by ten cycles of $30 \mathrm{~s}$ each at $94^{\circ} \mathrm{C}, 1 \mathrm{~min}$ at $60-50^{\circ} \mathrm{C}$ (touchdown of $-1^{\circ} \mathrm{C}$ per cycle) and $30 \mathrm{~s}$ at $70^{\circ} \mathrm{C}$, followed by 30 cycles of $30 \mathrm{~s}$ at $94^{\circ} \mathrm{C}, 1 \mathrm{~min}$ at $55^{\circ} \mathrm{C}$, and $1 \mathrm{~min}$ at $72^{\circ} \mathrm{C}$ with a final extension of $20 \mathrm{~min}$ at $72^{\circ} \mathrm{C}$. The PCR products were sequenced by Eurofins Genomics (http://www.eurofinsgenomics.eu/). All voucher specimens sequenced were mounted, dried and deposited at the Centre de Biologie pour la Gestion des Populations, Montpellier, France (CBGP, CIRAD collection https://doi.org/10.15454/D6XAKL). Barcode sequences were aligned using CodonCode Aligner ver. 3.7.1. (CodonCode Corporation, Centerville, MA, USA), and checked to identify the presence of pseudogenes using standard detection methods (Haran et al. 2015). Sequences were subjected to a BLAST (implemented in the NCBI platform https://www.ncbi.nlm.nih.gov/) to compare them to the existing sequences of species of Smicronyx (Haran et al. 2017; Haran 2018). Uncorrected p-distance values of pairwise genetic distances between species were computed with Mega 7 (Kumar et al. 2016).

\section{Results}

Class Insecta Linnaeus, 1758

Order Coleoptera Linnaeus, 1758

Superfamily Curculionoidea Latreille, 1802

Family Curculionidae Latreille, 1802

Subfamily Curculioninae Latreille, 1802

Tribe Smicronychini Seidlitz, 1891

Genus Sharpia Tournier, 1873

Sharpia madibai sp. nov. urn:lsid:zoobank.org:act:35B8B4E7-A313-462E-8C2C-B892485E39EE

Figs 1A, 3A, 5A; Table 1

\section{Differential diagnosis}

Sharpia madibai sp. nov. is mostly similar to $S$. soluta Faust, 1885, a species widely distributed in the Mediterranean region on Convolvulus dorycnium Linnaeus, 1759 (Friedman 2017). It can be distinguished from it by the absence of spots of white scales in the middle of interstria 2-3 (S. soluta shows such spots), and by the shape of the penis very elongate [ratio w/l: 0.15 ] with a series of small 
Table 1. Checklist, distribution and host plants of Smicronyx of southern Africa.

\begin{tabular}{|c|c|c|c|}
\hline Species & Distribution & Host plant & $\begin{array}{l}\text { GenBank } \\
\text { accession }\end{array}$ \\
\hline 1. Sharpia madibai sp. nov. & Namibia, Rep. of S.A. & - & - \\
\hline 2. Afrosmicronyx cycnii sp. nov. & Rep. of S.A. & Cycnium adonense & - \\
\hline 3. Afrosmicronyx louwi sp. nov. & Rep. of S.A. & - & - \\
\hline 4. Afrosmicronyx marshalli sp. nov. & Rep. of S.A. & - & - \\
\hline 5. Afrosmicronyx nebulosipennis sp. nov. & Zimbabwe & - & - \\
\hline 6. Smicronyx gracilipes sp. nov. & Rep. of S.A. & - & MT370314 \\
\hline 7. Smicronyx similis sp. nov. & Rep. of S. A., Zimbabwe & - & - \\
\hline 8. Smicronyx pseudocoecus sp. nov. & Rep. of S.A. & Cuscuta nitida, Cuscuta sp. & MT370315 \\
\hline 9. Smicronyx paucisquamis sp. nov. & Rep. of S.A. & Cuscuta sp. & - \\
\hline 10. Smicronyx fallax Gyllenhal, 1836 & Namibia, Rep. of S.A. & Cuscuta campestris, Cuscuta sp. & МТ370316-17 \\
\hline 11. Smicronyx australis sp. nov. & Rep. of S.A. & Cuscuta nitida & MT370318 \\
\hline 12. Smicronyx pauperculus Wollaston, 1864 & $\begin{array}{l}\text { Afrotropical region, } \\
\text { Mediterranean region, } \\
\text { Near East, Pakistan }\end{array}$ & Cuscuta campestris & $\begin{array}{l}\text { KU942318 } \\
\text { KU942313 }\end{array}$ \\
\hline 13. Smicronyx san sp. nov. & Rep. of S.A. & $\begin{array}{c}\text { Chironia baccifera, Orphium, } \\
\text { Sebaea aurea, Sebaea spp. }\end{array}$ & МT370319 \\
\hline 14. Smicronyx drakensbergensis sp. nov. & Rep. of S.A. & - & - \\
\hline 15. Smicronyx zonatus Haran, 2018 & $\begin{array}{l}\text { Liberia, Democratic Re- } \\
\text { public of Congo, Rep. of } \\
\text { S.A., Zambia }\end{array}$ & Orobanchaceae (nr. Euphrasia) & MH898571 \\
\hline 16. Smicronyx lutulentus Dietz, 1894 & $\begin{array}{l}\text { Central and North America, } \\
\text { Rep. of S.A. (introduced) }\end{array}$ & $\begin{array}{l}\text { Parthenium hysterophorus } \\
\text { (introduced) }\end{array}$ & MT370320 \\
\hline 17. Smicronyx albosquamosus Wollaston, 1854 & $\begin{array}{l}\text { Mediterranean region, } \\
\text { Rep. of S.A., Zambia }\end{array}$ & Cuscuta sp. & KC783772 \\
\hline 18. Smicronyx namibicus Haran, 2018 & $\begin{array}{l}\text { Rep. of S.A., Tanzania } \\
\text { (Island of Zanzibar) }\end{array}$ & - & - \\
\hline
\end{tabular}

erect setae on sides in $S$. madibai sp. nov., moderately elongate in $S$. soluta (ratio w/l: 0.25 ) and bare of setae).

\section{Etymology}

This species is dedicated to Nelson Mandela 'Madiba' for the role he played in the history of the Republic of South Africa.

\section{Material examined}

Holotype

REPUBLIC OF SOUTH AFRICA • 1 § ; "S. Africa. Tvl. [Mpumalanga Province]; Kruger N. Pk. [National Park] nr. Satara; 15-18 .XII.1985; H. \& A. Howden" / "HolotYPE; Sharpia madibai; Haran 2021"; SAMC.

\section{Paratypes}

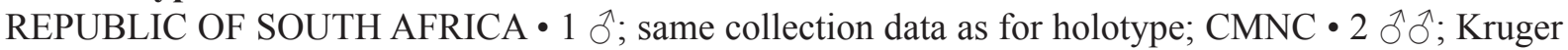
National Park, Lower Sabie; 14 Dec. 1985; M. Sanborne leg.; sweeping; CMNC • 1 q; same collection data as for preceding; 16 Dec. 1985; M. Sanborne leg.; sweeping; CMNC 1 đ; Northern Cape Province, Witsand Nature Reserve; 28.33 S, 22.29 E; alt. 1165 m; 6 Feb. 2012; R. Müller leg.; at light; TMSA - 1 ; Limpopo Province, Atherstone Nature Reserve, 20 km west Dwaalboom; 24.36 S, 26.46 E; 17 
Apr. 1999; M. Stiller leg.; SANC • 1 q; Northern Cape Province, Tsawu, Nas. K. W.; 17 Mar. 1970; H.A.D. van Schalkwyk leg.; SANC • 1 ơ; Northern Cape Province, Tswalu Kalahari Reserve, road between hills; $27^{\circ} 15.387^{\prime}$ S; $22^{\circ} 27.810^{\prime}$ E; 31 Oct. 2018; R. Borovec leg.; FFWS.

NAMIBIA • 1 o; Weldevrede Guest Farm; 24.10 S, 15.58 E; alt. 1105 m; 11-13 Feb. 2010; R. Müller leg.; TMSA • 1 ; Kaokoveld Ohopoho town; 18.03 S, 13.48 E; 13 Feb. 1975; Endrödy and Schulze leg.; at light; TMSA.

\section{Description}

BoDy LENGTH. 2.4-3.0 mm.

Colour. Body integument reddish brown; vestiture consisting of imbricated scales, polygonal, shiny, completely concealing the integument, scales dark brown, pale brown and white, with white scales generally condensed along the median line of prothorax, forming a white band in the middle of $4^{\text {th }}$ interstria and near apex of interstria $1-3$.

HEAD. Rostrum as long as head + prothorax and regularly downcurved in lateral view, thicker than protibiae in dorsal view, densely punctuate and striate $\left({ }^{\Uparrow}\right)$, smooth with small punctures in apical half $\left(+\right.$ ), basal $2 / 3\left({ }^{\lambda}\right)$ or basal half $(+)$ of upper side bearing dense cover of pale brown scales, upper side of scrobes forming a carina slightly expanding basally near eyes; transverse furrow at base of rostrum narrow, shiny, bare of scales, with two spots of erect white scales on side near eyes; head capsule short, densely covered with scales; antennae inserted at apical $1 / 3\left(\delta^{\Uparrow}\right)$ or near middle of length (ㅇ) with segment 1 longer than $2+3,4$ isodiametric, segments 5-7 wider than long.

Prothorax. Slightly wider than long (ratio w/l: 1.02), widest in basal $1 / 3$ of length, greatly narrowed at apex, integument concealed with rounded, almost hexagonal scales, and few scattered suberect, elongate, white scales oriented toward the centre of prothorax.

ELYTRA. Sides subparallel in basal $2 / 3$, slightly expanding toward middle of length, widest near middle (ratio w/l: 0.71), humeri raised; declivital callosities on interval 5 present but weak, followed by a depression; striae narrow, $1 / 2-2 / 3$ width of interstriae; interstriae flat, shiny, bearing two series of imbricated scales and one series of suberect elongate scales; scutellum very small.

АвDOMEn. Underside densely covered with white and grey, elliptical, overlapping scales.

LEGS. Femora clavate, unarmed; tibiae straight, unarmed, slightly bisinuate on ventral side; claws equal in length.

Genitalia. Body of penis very elongate (ratio w/1: 0.15 ), $2 \times$ as long as apodemes, sides slightly convex, widest near basal $1 / 3$, straight and converging toward apex in apical $2 / 3$, apex rounded, curvature in lateral view weak, mainly in basal half (Fig. 5A).

\section{Life history}

Host plant unknown, adults collected by sweeping vegetation. Sharpia Tournier, 1873 spp. are commonly collected on perennial non-parasitic Convolvulaceae.

\section{Distribution}

Namibia, Republic of South Africa (Kruger National Park, Northern Cape Province). 
Genus Afrosmicronyx Hustache, 1935

Afrosmicronyx cycnii sp. nov.

urn:1sid:zoobank.org:act:13BC63BD-16FB-4F63-A4C1-183285E1BAA9

Figs 1B, 3B, 5B; Table 1

\section{Differential diagnosis}

This species is mostly similar to Afrosmicronyx angolanus (Hustache, 1935), a species distributed in Angola (Haran \& Perrin 2017). The two species can be distinguished by the protibial tooth (well developed in A. angolanus, absent or very small in $A$. cycnii sp. nov.), the scales on the elytra (dense, rounded, with a copper shine in $A$. angolanus, scattered, elliptic and greyish in $A$. cycnii sp. nov.), and the shape of the penis (sides rounded in A. angolanus, sides straight and regularly converging from base to apex in $A$. cycnii sp. nov.).

\section{Etymology}

This species is named in reference to the genus of the host plant Cycnium adonense E. Mey. ex Benth., on which the type series was collected.

\section{Material examined}

Holotype

REPUBLIC OF SOUTH AFRICA • 1 ; ; "South Africa Tvl. [Mpumalanga Province]; Schoemanskloof valley; m 1200 - 25.19'S 30.40'E; 14.XI.1988 - Colonnelli” / "On; Cycnium; adonense E. Mey. Ex. Benth." / "НоLотүPE; Afrosmicronyx cycnii; Haran 2021”; SAMC.

\section{Paratypes}

REPUBLIC OF SOUTH AFRICA • 1 ô; same collection data as for holotype; SANC $\bullet 1$; same

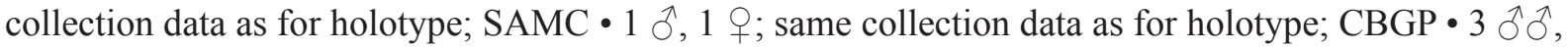
7 우; same collection data as for holotype; MCZ.

\section{Description}

BoDy LENGTH. 2.9-3.7 mm.

CoLour. Body integument black; vestiture consisting of short rounded recumbent scales, longer than wide, black, not concealing the integument.

HEAD. Rostrum longer than head + prothorax in lateral view, moderately downcurved, thicker than protibia in middle in dorsal view, densely punctuate and striate, punctures and striae smoother near apex, basal $1 / 4$ of upper side bearing small suberect black setae, upper side of scrobes forming a carina with a small tooth basally near eyes; transverse furrow at base of rostrum shiny, bare of scales; head capsule short, bare of scales; antennae with segment 1 as long as $2+3,4-6$ isodiametric, segment 7 wider than long.

Prothorax. Isodiametric (ratio w/l: 1), widest at basal 1/3, greatly narrowed at apex, densely and coarsely punctuate, median line smooth and slightly raised.

ELYTRA. Sides subparallel in basal $2 / 3$, slightly expanding toward middle of length, widest after middle (ratio w/l: 0.65), humeri raised; declivital callosities on interval 5 present but weak, followed by a depression, striae narrow, $1 / 4$ width of interstriae; interstriae flat, shiny, bearing 2-3 ill-defined series of scales; scutellum small, shiny, bare of scales. 

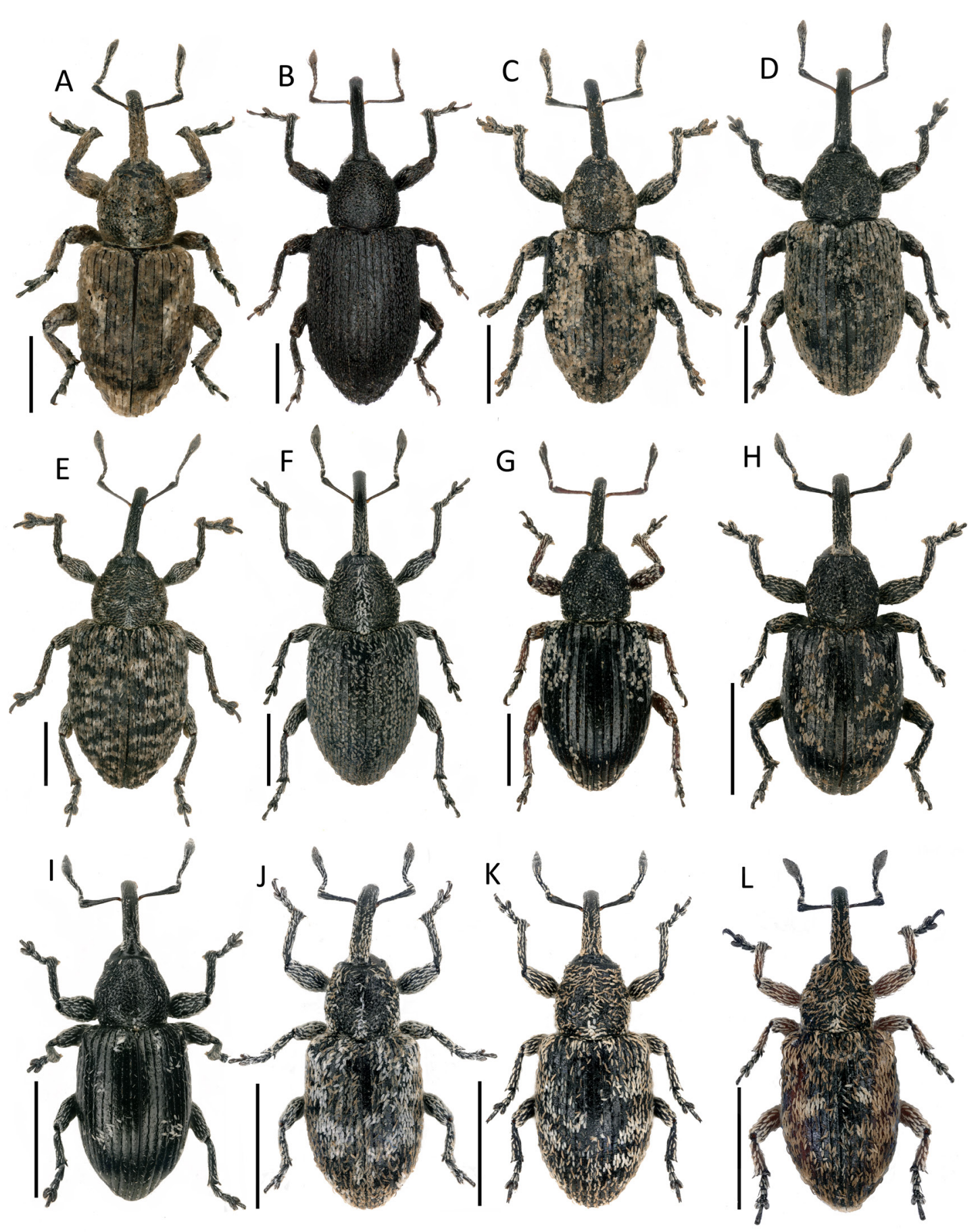

Fig. 1. Habitus of species of Smicronychini from southern Africa (Part 1). A. Sharpia madibai sp. nov., $\hat{\jmath}$, holotype (SAMC). B. Afrosmicronyx cycnii sp. nov., ô, holotype (SAMC). C. Afrosmicronyx

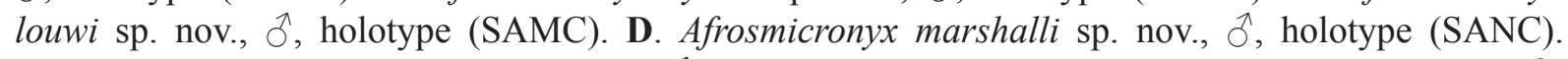
E. Afrosmicronyx nebulosipennis sp. nov., $\widehat{\jmath}$, holotype (BMNH). F. Smicronyx gracilipes sp. nov., + , holotype (SAMC). G. Smicronyx similis sp. nov., $\widehat{\jmath}$, holotype (SANC). H. Smicronyx pseudocoecus

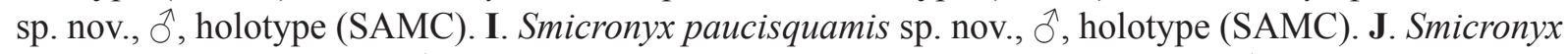
fallax (Gyllenhal, 1836), §, neotype (NHRS). K. Smicronyx australis sp. nov., §, holotype (SAMC). L. Smicronyx pauperculus Wollaston, 1864, $\hat{\partial}$, specimen from Tanzania. Scale bars: $1 \mathrm{~mm}$. 
AвDOMEn. Underside covered with greyish scattered scales, $3 \times$ as long as wide, with a metallic-copper shine; ventrite 1 shorter than 2 .

LEGS. Femora clavate, armed with one ventral tooth; tibiae straight, bearing a moderate thickening ventrally, sometimes almost forming a tooth on protibiae, facing femoral tooth when legs are folded; claws equal in length.

Genitalia. Body of penis short (ratio w/l: 0.42), as long as apodemes, sides straight, regularly converging from base to apex, apex rounded, curvature in lateral view regular (Fig. 5B).

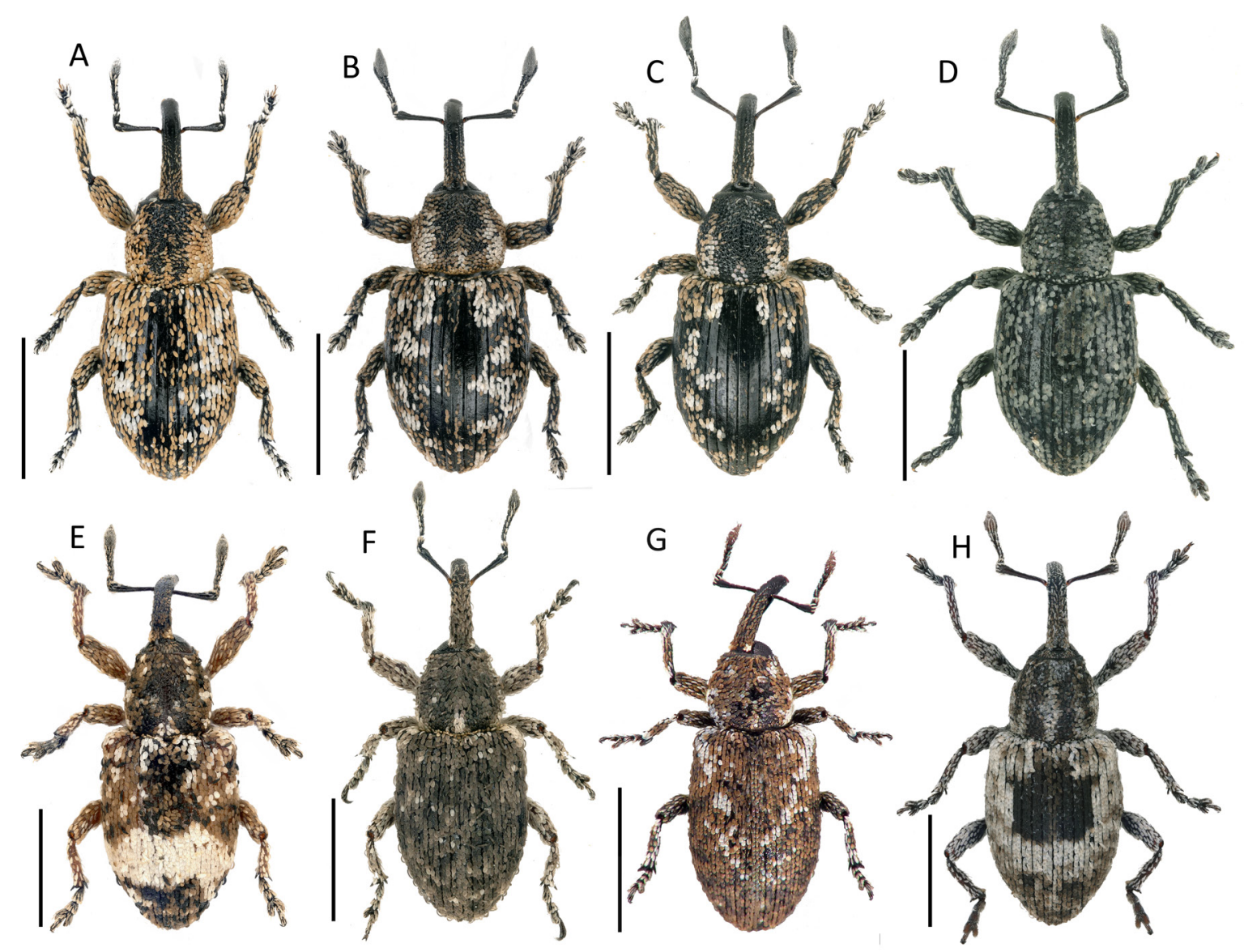

Fig. 2. Habitus of species of Smicronychini from southern Africa (Part 2). A. Smicronyx san sp. nov., Ô, holotype (SAMC), bred from Chironia baccifera L. B. S. san sp. nov., Ô, paratype (CBGP), specimen bred from Orphium frutescens L. (E. Mey). C. S. san sp. nov., đ̃, paratype (CBGP), specimen bred from Sebaea Sol. ex R.Br. sp. D. Smicronyx drakensbergensis sp. nov., ô, holotype (TMSA). E. Smicronyx

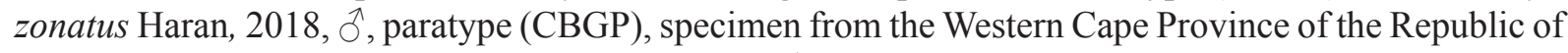
South Africa. F. Smicronyx lutulentus Dietz, 1894, ô (CBGP). G. Smicronyx albosquamosus Wollaston, 1854, $\widehat{\jmath}$ (CBGP), specimen from Israel. H. Smicronyx namibicus Haran, 2018, $\widehat{\jmath}$ (MNHN), specimen from Tanzania. Scale bars: $1 \mathrm{~mm}$. 


\section{Sexual dimorphism}

Females are distinguished from males by their rostrum, which is slightly longer, and more downcurved in lateral view.

\section{Life history}

All the specimens of this species were collected on Cycnium adonense E. Mey. Ex. Benth., 1835 (Orobanchaceae) a hemiparasitic plant parasite of grass. Adults were collected in November in the Republic of South Africa.

\section{Distribution}

Republic of South Africa (Mpumalanga Province).

$$
\begin{aligned}
& \text { Afrosmicronyx louwi sp. nov. } \\
& \text { urn:1sid:zoobank.org:act:90CD8ADD-9841-4742-B4BF-61E6F709EDA0 }
\end{aligned}
$$

Figs 1C, 3C, 5C; Table 1

\section{Differential diagnosis}

Afrosmicronyx louwi sp. nov. is mostly similar to A. madagascariensis Haran, 2018. The two species can be distinguished by their size (body length 3.4-3.6 $\mathrm{mm}$ in A. madagascariensis, $2.5 \mathrm{~mm}$ in A. louwi sp. nov.), the protibial tooth (moderately thickened in $A$. louwi sp. nov., strongly thickened tooth in A. madagascariensis) and the shape of the penis (sides subparallel, thickened in middle in lateral view in A. louwi sp. nov., sides convex, thickness regular in lateral view in A. madagascariensis).

\section{Etymology}

This species is dedicated to the late Dr. Schalk Louw, for his contribution to the knowledge of southern African weevils.

\section{Material examined}

\section{Holotype}

REPUBLIC OF SOUTH AFRICA • 1 गे; "Natal [Kwazulu-Natal Province]; Malvern" / "N. Barkers; 190" "SAM-COL-;A073094" / "Holotype; Afrosmicronyx louwi; Haran 2021”; SAMC.

\section{Description}

\section{Male}

BODY LENGTH. $2.5 \mathrm{~mm}$.

CoLour. Body integument black; vestiture consisting of rounded recumbent scales, as long as wide or slightly elliptical, brown and greyish on elytra.

HEAD. Rostrum as long as head + prothorax in lateral view, moderately and regularly downcurved, slightly wider than protibiae in dorsal view, punctate and striate, smooth at apex, covered with scales in basal $2 / 3$, less densely in apical $1 / 3$, upper side of scrobes forming a carina with a small tooth basally near eyes, transverse furrow at base of rostrum shiny, bare of scales; antennae black, inserted before apical $1 / 3$, segment 1 slightly longer than $2+3,4$ isodiametric, 5-7 wider than long.

Prothorax. Wider than long (ratio w/1: 1.14), widest slightly before middle of length, greatly narrowed at apex, sides rounded; integument shiny, densely granulate; scales brownish and greyish, longer than wide, generally concealing granules, forming two paler bands laterally to the median line. 
ELYTRA. Sides moderately convex, straight and expanding apicad in basal 1/2, rounded in apical 1 12 , widest near middle (ratio w/l: 0.70); humeri raised; striae narrow, interstriae flat, wide and shiny, covered with 2-3 series of aligned scales, apex of interstria 5 with slight declivital callosity, followed by depression; scutellum small but visible.

Abdomen. Underside covered with rounded brownish-grey scales, not concealing the integument.

Legs. Dark brownish, femora clavate, armed with one ventral tooth; tibiae bearing a moderate thickening ventrally, facing femoral tooth when legs are folded; claws equal in length.

Genitalia. Body of penis elongate (ratio w/1: 0.36), sides parallel, converging near apex, apex rounded, curvature regular in lateral view, thicker in apical half. (Fig. 5C). Female not known.

\section{Life history}

Unknown.

\section{Distribution}

Republic of South Africa (KwaZulu-Natal Province).

Afrosmicronyx marshalli sp. nov. urn:lsid:zoobank.org:act:E0C45446-219B-4B9D-8714-3C94C28D3DDF

Figs 1D, 3D, 5D; Table 1

\section{Differential diagnosis}

Afrosmicronyx marshalli sp. nov. is mostly similar to A. angolanus, a species distributed in Angola and Kenya (Haran \& Perrin 2017). The two species can be distinguished from each other by the shape of their prothorax (wider than long in A. marshalli sp. nov., isodiametric in A. angolanus) and their protibiae (with a thickening at middle in $A$. marshalli sp. nov., armed with an acute tooth in $A$. angolanus).

\section{Etymology}

Afrosmicronyx marshalli sp. nov. is dedicated to Sir Guy A. K. Marshall for his outstanding contribution to the knowledge on African weevils and particularly on the southern African fauna.

\section{Material examined}

\section{Holotype}

REPUBLIC OF SOUTH AFRICA • 1 ô;; "Nr. Belfast; Tvl. [Mpumalanga Province]; 14 Jan. 1963; A L Capener" / "National Coll.; of Insects; Pretoria, S. Afr" / "Holotype; Afrosmicronyx marshalli; Haran 2021"; SANC.

\section{Paratype}

REPUBLIC OF SOUTH AFRICA • 1 क; same collection data as for holotype; SAMC.

\section{Description}

BODY LENGTH. 3.0-3.2 mm.

Colour. Body integument black; vestiture consisting of rounded recumbent scales, as long as wide or elliptical, greyish on elytra. 
HEAD. Rostrum equal ( $(\hat{)})$ or slightly longer than head capsule plus prothorax (o) in lateral view, moderately downcurved, in dorsal view covered with scales only in basal $1 / 3$, shiny and slightly punctate in apical $2 / 3$; antennae inserted slightly after middle of length; transverse furrow at base of rostrum shiny, with two spots of whitish semi-erect scales on sides near eyes; head capsule glabrous; eyes flat, subcontiguous ventrally, distance between eyes equal to the width of 1-2 ommatidia; antennal scape slightly bisinuate at base, moderately clavate at apex, segment 1 of funicle elongate, as long as $2+3$, 3-7 wider than long.

Prothorax. Slightly wider than long (ratio w/l: 1.08), widest near middle of length, greatly narrowed at apex, sides strongly rounded; integument shiny, densely granulate; scales greyish, longer than wide.

ElYTRA. Sides convex, widest near middle (ratio w/l: 0.7); humeri raised; striae narrow, interstriae flat, wide and shiny, striae $1 / 3$ width of interstriae, covered with two or three series of aligned scales, apex of interstria 5 with slight declivital callosity, followed by a depression; scutellum small but visible.

AвDOMEN. Underside covered with elliptical greyish scales, not concealing the integument.

LEGS. Integument black, femora clavate, armed with one ventral tooth; tibiae bearing a thickening $(\widehat{\delta})$ or a tooth $($ ( $)$ ventrally, facing femoral tooth when legs are folded; claws equal in length.

Genitalia. Body of penis short (ratio w/l: 0.56 ), about $0.7 \times$ as long as apodemes, sides convex, converging near apex, apex truncate, curvature in lateral view stronger near apex (Fig. 5D).

\section{Life history}

Unknown.

\section{Distribution}

Republic of South Africa (Mpumalanga Province).

Afrosmicronyx nebulosipennis sp. nov. urn:lsid:zoobank.org:act:7AF87EB3-BC0C-486C-849B-8A4A1B681A4E

Figs 1E, 3E, 5E; Table 1

\section{Differential diagnosis}

Afrosmicronyx nebulosipennis sp. nov. is mostly similar to A. umbrinus Hustache, 1940, a species widely distributed from West to East Africa (Anderson \& Cox 1997). The body length of A. nebulosipennis sp. nov. $(3.6-3.8 \mathrm{~mm})$ is slightly shorter than in A. umbrinus $(3.8-4.0 \mathrm{~mm})$ and its general appearance is more robust. Segment 3 of the antennal funicle is wider than long in A. nebulosipennis sp. nov. while it is isodiametric in A. umbrinus. The penis in A. nebulosipennis sp. nov. is more elongate and its sides more rounded (Fig. 5E) than in $A$. umbrinus.

\section{Etymology}

Afrosmicronyx nebulosipennis sp. nov. is named in reference to the ill-defined shades of its elytral vestiture.

\section{Material examined}

Holotype

ZIMBABWE • 1 万े; "Salisbury [Harare]; Oct. 1903; G A K M [Marshall]" / "Pres. By; Imp. Inst. Ent.; BMNH(E) 1996" / "HoLotyPE; Afrosmicronyx nebulosipennis; Haran 2021”; BMNH. 
Paratypes

ZIMBABWE $\bullet 2 \hat{\jmath}, 2$ 우; same collection data as for holotype; BMNH.

\section{Description}

BODY LENGTH. 3.6-3.8 mm.

Colour. Body integument black; vestiture consisting of rounded recumbent scales, elliptical, twice as long as wide, forming grey, brown and/or white, ill-defined transverse bands on elytra.

HEAD. Rostrum distinctly longer than head capsule + prothorax in lateral view, downcurved at base, almost straight in the rest of the length, covered by scales on the upper face only in basal $1 / 2\left(\delta^{\pi}\right)$ or in basal $1 / 3(+)$; integument punctuate; antennae inserted at apical $1 / 3$; transverse furrow at base of rostrum covered with whitish scales, with two spots of semi-erect whitish or brownish scales on sides near eyes; head capsule glabrous except near transverse furrow; eyes flat, subcontiguous ventrally, distance between eyes equal or shorter than width of 1-2 ommatidia; antennal scape slightly bisinuate at base, moderately clavate at apex, segment 1 of funicle elongate, as long as $2+3,3-5$ isodiametric, $6-7$ wider than long.

Prothorax. Isodiametric (ratio w/l: 1), widest slightly before middle of length, greatly narrowed at apex, sides strongly rounded; integument shiny, densely granulate; scales brownish, $3 \times$ as long as wide, converging to the median line.

ELYTRA. Sides subparallel in basal half, widest near middle (ratio w/l: 0.74), convex in apical half; humeri raised; striae narrow, interstriae flat, $4 \times$ as wide as striae, integument shiny and rough, covered with two or three series of aligned scales, apex of interstria 5 with a declivital callosity, followed by a depression; base of interstria 3 with a spot of white scales; scutellum rounded, small but visible.

AвDOMEN. Underside covered with elliptical greyish scales, not concealing the integument; ventrite 2 as long as $3-5$.

LEGS. Integument black, femora clavate, armed with a strong ventral tooth; tibiae bearing an acute tooth ventrally, before middle of length, facing femoral tooth when legs are folded; claws equal in length.

Genitalia. Body of penis short (ratio w/l: 0.55), as long as apodemes, sides parallel, apex flat with an acute cuticular expansion, curvature in lateral view moderate and regular (Fig. 5E).

\section{Life history}

Unknown.

\section{Distribution}

Zimbabwe (Harare). 
Genus Smicronyx Schoenherr, 1843

Smicronyx gracilipes sp. nov. urn:1sid:zoobank.org:act:BE18ED2E-7D6F-42C7-8550-59B004B62C95 Figs 1F, 3F; Table 1

\section{Differential diagnosis}

Smicronyx gracilipes sp. nov. is closest to $S$. guineanus Voss, 1956, but $S$. gracilipes sp. nov. is lacking or has a very small femoral tooth (well developed in $S$. guineanus), a less dense coating of scales on the elytra (almost concealing the integument in $S$. guineanus). The sequences of the COI show that S. gracilipes sp. nov. is distinct by $8.7 \%$ [GB accession: MT370314] with specimens of S. guineanus from Niger.

\section{Etymology}

The species epithet refers to the remarkable long and thin legs encountered in this species.

\section{Material examined}

\section{Holotype}

REPUBLIC OF SOUTH AFRICA - 1 q; "Rep. of South Africa; Underberg, [KwaZulu-Natal Province]; 29³46'37.42"S 29³0'00.44"E; 1579 m, 30.xii.2018; J. Haran leg." / "Beating flowers of; Anacardiacaeae; JHAR02024_0101" / "HolotyPE; Smicronyx gracilipes; Haran 2021"; SAMC.

\section{Description}

\section{Female}

Body LeNGTH. $2.5 \mathrm{~mm}$.

Colour. Body integument black, antennae dark brown; vestiture of elytra made of recumbent scales, elliptic, not overlapping, twice as long as wide, grey, aligned in 2-3 ill-defined series on each interstria;

HEAD. Rostrum slightly longer than head capsule + prothorax in lateral view, moderately downcurved, in dorsal view covered with scarce scales in basal $1 / 3$ and very short white setae in apical $2 / 3$, punctate over entire length, smooth at apex; antennae inserted near middle of length; transverse furrow at base of rostrum shiny, with two spots of whitish erect scales on sides near eyes; head capsule glabrous, with slight cover of scales near transverse furrow; eyes flat, subcontiguous ventrally, distance between eyes equal to the width of two ommatidia; antennal scape slightly bisinuate at base, moderately clavate at apex, segment 1 elongate, as long as $2+3,4-5$ isodiametric, 6-7 wider than long.

Prothorax. Slightly wider than long (ratio w/l: 1.05), widest near middle, sides rounded, narrowed in apical 1/4; integument smooth, shiny, with small punctures; scales brown, elongate, not concealing the integument, with grey scales forming a pale band along the median line and two on the sides of prothorax.

ELYTRA. Sides slightly convex, widest near middle (w/1 ratio: 0.74 ); humeri raised; striae 1/3 width of interstriae, interstriae flat, shiny, interstria 5 with a moderate declivital callosity near apex, followed by a slight depression; scutellum small but visible.

AвDOMEN. Underside mostly covered with non-overlapping greyish scales, twice as long as wide.

LEGS. Femora clavate, unarmed or bearing a very small ventral tooth in middle; tibiae straight, unarmed, claws equal in length. Males unknown. 

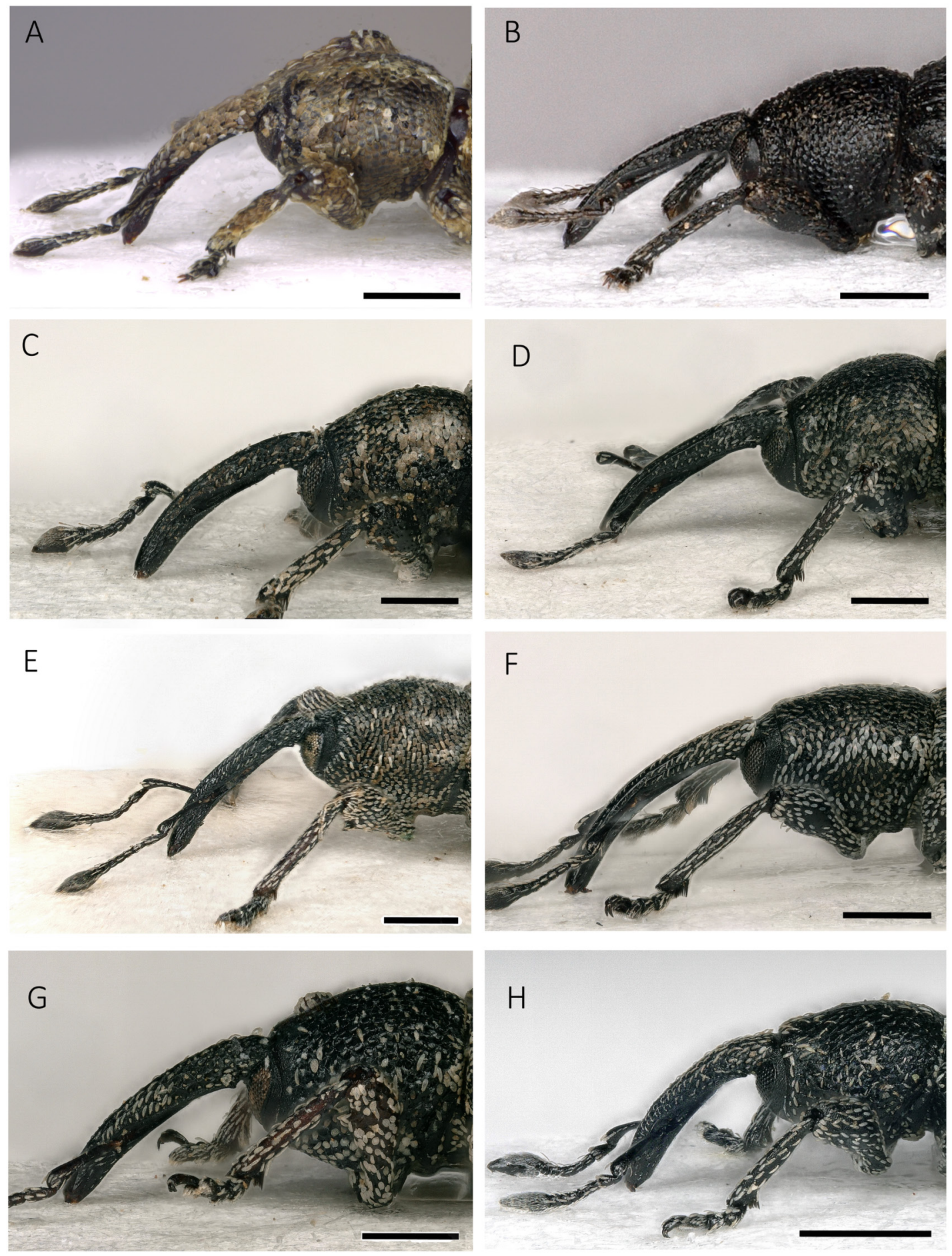

Fig. 3. Head and prothorax in lateral view of species of Smicronyx from southern Africa (Part 1). A. Sharpia madibai sp. nov., §̂, holotype (SAMC). B. Afrosmicronyx cycnii sp. nov., đ̂, holotype (SAMC). C. Afrosmicronyx louwi sp. nov., Ô, holotype (SAMC). D. Afrosmicronyx marshalli sp. nov., $\hat{\jmath}$, holotype (SANC). E. Afrosmicronyx nebulosipennis, sp. nov., $\widehat{\jmath}$, holotype (BMNH). F. Smicronyx

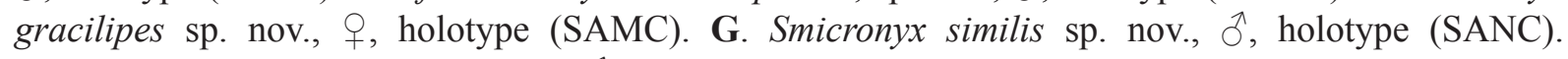
H. Smicronyx pseudocoecus sp. nov., ${ }^{\lambda}$, holotype (SAMC). Scale bars: $0.5 \mathrm{~mm}$. 


\section{Life history}

Host plant unknown. The holotype specimen was collected on flowers of an unidentified Anacardiaceous shrub surrounded by a large grassland. This specimen was collected in December.

\section{Distribution}

Republic of South Africa (KwaZulu-Natal Province).
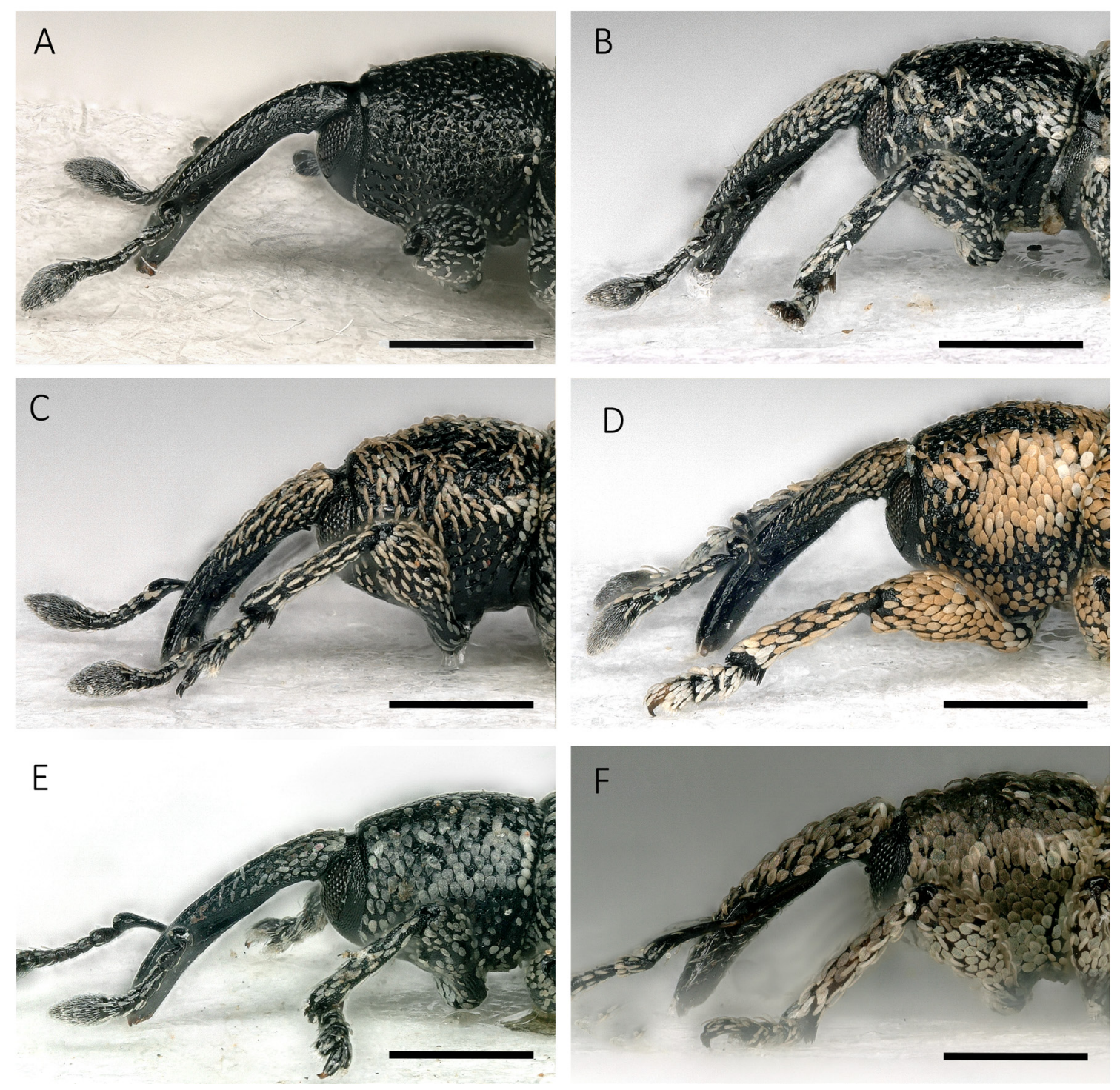

Fig. 4. Head and prothorax in lateral view of species of Smicronyx from southern Africa (Part 2). A. Smicronyx paucisquamis sp. nov., ô, holotype (SAMC). B. Smicronyx fallax (Gyllenhal, 1836), ð̂, neotype (NHRS). C. Smicronyx australis sp. nov., Ô, holotype (SAMC). D. Smicronyx san sp. nov., $\widehat{\jmath}$, bred from Chironia baccifera L., holotype (SAMC). E. Smicronyx drakensbergensis sp. nov., $\widehat{\partial}$, holotype (TMSA). F. Smicronyx lutulentus Dietz, 1894, §̊ (CBGP). Scale bars: $0.5 \mathrm{~mm}$. 


\section{Smicronyx similis sp. nov. urn:lsid:zoobank.org:act:14428DD9-227D-41C6-9062-C95EBF458451}

Figs $1 \mathrm{G}, 3 \mathrm{G}, 5 \mathrm{~F}$; Table 1

\section{Differential diagnosis}

Smicronyx similis sp. nov. is mostly similar to $S$. guineanus Voss, 1956, a species widely distributed in tropical Africa. The two species can be distinguished by their general appearance, which is more robust in $S$. similis sp. nov. The second segment of the funicle is isodiametric in S. similis sp. nov. while it is distinctly longer than wide in $S$. guineanus, the elytra are wider in $S$. similis sp. nov. than in S. guineanus (ratio w/l: 0.68 and 0.58 respectively), and the integument of the prothorax of S. similis sp. nov. is more coarsely punctate than in S. guineanus. The body of the penis in S. similis sp. nov. is also thicker and less narrowed in the middle than in $S$. guineanus. In southern Africa, S. similis sp. nov. is closest to $S$. gracilipes sp. nov., but the latter species has distinctly longer legs and rostrum and a finely punctate prothoracic integument (coarsely granulate in S. similis sp. nov.).

\section{Etymology}

The species name 'similis' refers to the similar appearance of this species with $S$. guineanus, which is a very widespread and abundant species in tropical Africa.

\section{Material examined}

\section{Holotype}

REPUBLIC OF SOUTHAFRICA • 1 đ̊; "S. Afr.; N Cape Prov.; Tswalu Nat. Res. 1162 m; 27.18S-22.26E" / "14.2.2005; E-Y [Endrödy-Younga leg.]; 3644; general [collecting] at Gosa lodge; Leg. M. Burger, R. Müller” / "НоцотүPE; Smicronyx similis; Haran 2021”; SANC.

\section{Paratype}

ZIMBABWE・ 1 q; Sebakwe; 1903; D. Dods leg.; SAM-COL-A073093; SAMC.

\section{Description}

BODY LENGTH. $2.5 \mathrm{~mm}$.

CoLour. Body integument black, shiny, antennae and legs reddish; vestiture of elytra with scattered, recumbent, brownish and whitish, rounded or elliptic scales, forming two ill-defined series on each interstria.

HEAD. Rostrum slightly longer than head capsule + prothorax, moderately downcurved in lateral view, slightly longer and more downcurved in $\rho$ than in $\partial^{\lambda}$, covered with scarce whitish scales dorsally $\left({ }^{\lambda}\right)$ or scales only in basal $1 / 4(+)$, shiny and slightly punctate at apex $\left({ }^{3}\right)$ or at apical $2 / 3(+)$; antennae inserted slightly after middle of length $\left(+\right.$ ) or at apical $1 / 3\left({ }^{\pi}\right)$; transverse furrow at base of rostrum shiny, with two spots of whitish semi-erect scales on sides near eyes; head capsule glabrous, with slight cover of scales near transverse furrow; eyes flat, subcontiguous ventrally, distance between eyes equal to the width of 1-2 ommatidia; antennal scape slightly bisinuate at base, moderately clavate at apex, segment 1 of funicle elongate, slightly longer than $2+3,4-7$ wider than long.

Prothorax. Isodiametric (w/l ratio: 1), widest before middle, sides strongly rounded, narrowed in apical $1 / 4$; integument densely and strongly granulate, shiny.

ELYTRA. Sides slightly convex, widest near middle of length (w/1 ratio: 0.68 ); humeri raised; interstriae flat, shiny, $1 / 2-1 / 3 \times$ as wide as striae, interstria 5 with a moderate declivital callosity near apex, followed by a slight depression; scutellum small but visible. 
AвDOMEN. Underside mostly covered with non-overlapping greyish scales, twice as long as wide.

LEGS. Femora clavate, armed with a small ventral tooth in middle; tibiae straight, unarmed; claws equal in length.

Genitalia. Body of penis elongate (w/1 ratio: 0.23 ), $2 \times$ longer than apodemes, sides sub-parallel in basal $1 / 3$, narrowed near middle of length, spatulate in apical $1 / 3$, apex slightly acuminate, curvature in lateral view regular (Fig. 5F).

\section{Life history}

Unknown.

\section{Distribution}

Republic of South Africa (Northern Cape Province), Zimbabwe.

Smicronyx pseudocoecus sp. nov. urn:1sid:zoobank.org:act:FC3639AF-2419-4EBD-A3AF-2F6480677DE8

Figs $1 \mathrm{H}, 3 \mathrm{H}, 5 \mathrm{G}, 6 \mathrm{C}$; Table 1

\section{Differential diagnosis}

Smicronyx pseudocoecus sp. nov. is closest to the Palaearctic species $S$. coecus (Reich, 1797). These species can be distinguished by their claws, which are very slightly unequal in length in S. pseudocoecus sp. nov. while they are very distinctly unequal in $S$. coecus. The two species also show a p-distance of $8.7 \%$ on COI (GB accession: MT370315 / KC784156). In the Republic of South Africa, S. pseudocoecus sp. nov. is closest to $S$. paucisquamis sp. nov., a species found in Limpopo Province. S. pseudocoecus sp. nov. shows a denser elytral vestiture (Fig. 1H-I) and a more sclerified body of the penis (Fig. 5G-H) than S. paucisquamis sp. nov..

\section{Etymology}

Named in reference to the similar appearance of this species and S. coecus (Reich, 1797).

\section{Material examined}

\section{Holotype}

REPUBLIC OF SOUTH AFRICA • 1 §; "Rep. of South Africa; Paarl Mt. [Mountain] Nat. [Nature] Res. [Reserve] [Western Cape Province]; 334․056'S 18 56.773'E; 410 m, 4.iii.2018; J. Haran leg." / "on Cuscuta sp.; JHAR00783” / "HoLOTYPE; Smicronyx pseudocoecus; Haran 2021”; SAMC.

Fig. 5 (opposite page). Penis of Smicronyx from southern Africa, in dorsal (left) and lateral (right) view. A. Sharpia madibai sp. nov., ô, holotype (SAMC). B. Afrosmicronyx cycnii sp. nov., §̂, holotype (SAMC). C. Afrosmicronyx louwi sp. nov., ô, holotype (SAMC). D. Afrosmicronyx marshalli sp. nov., ${ }^{\lambda}$, holotype (SANC). E. Afrosmicronyx nebulosipennis sp. nov., ô, holotype (BMNH). F. Smicronyx similis sp. nov., §, holotype (SANC). G. Smicronyx pseudocoecus sp. nov., §, holotype (SAMC). H. Smicronyx paucisquamis sp. nov., ô, holotype (SAMC). I. Smicronyx fallax (Gyllenhal, 1836), ô, neotype (NHRS). J. Smicronyx australis sp. nov., ${ }^{\lambda}$, holotype (SAMC). K. Smicronyx pauperculus Wollaston, 1864, §̂, specimen from Tanzania. L. Smicronyx san sp. nov., §̃, holotype (SAMC), bred from Chironia baccifera L. M. Smicronyx drakensbergensis sp. nov., ô, holotype (TMSA). N. Smicronyx zonatus Haran, 2018, $\widehat{0}$, paratype (CBGP), specimen from the Western Cape Province of the Republic of South Africa. O. Smicronyx lutulentus Dietz, 1894, ô (CBGP). P. Smicronyx namibicus Haran, 2018, ${ }^{\lambda}$, holotype (MNHN), specimen from Tanzania. Scale bars: $100 \mu \mathrm{m}$. 

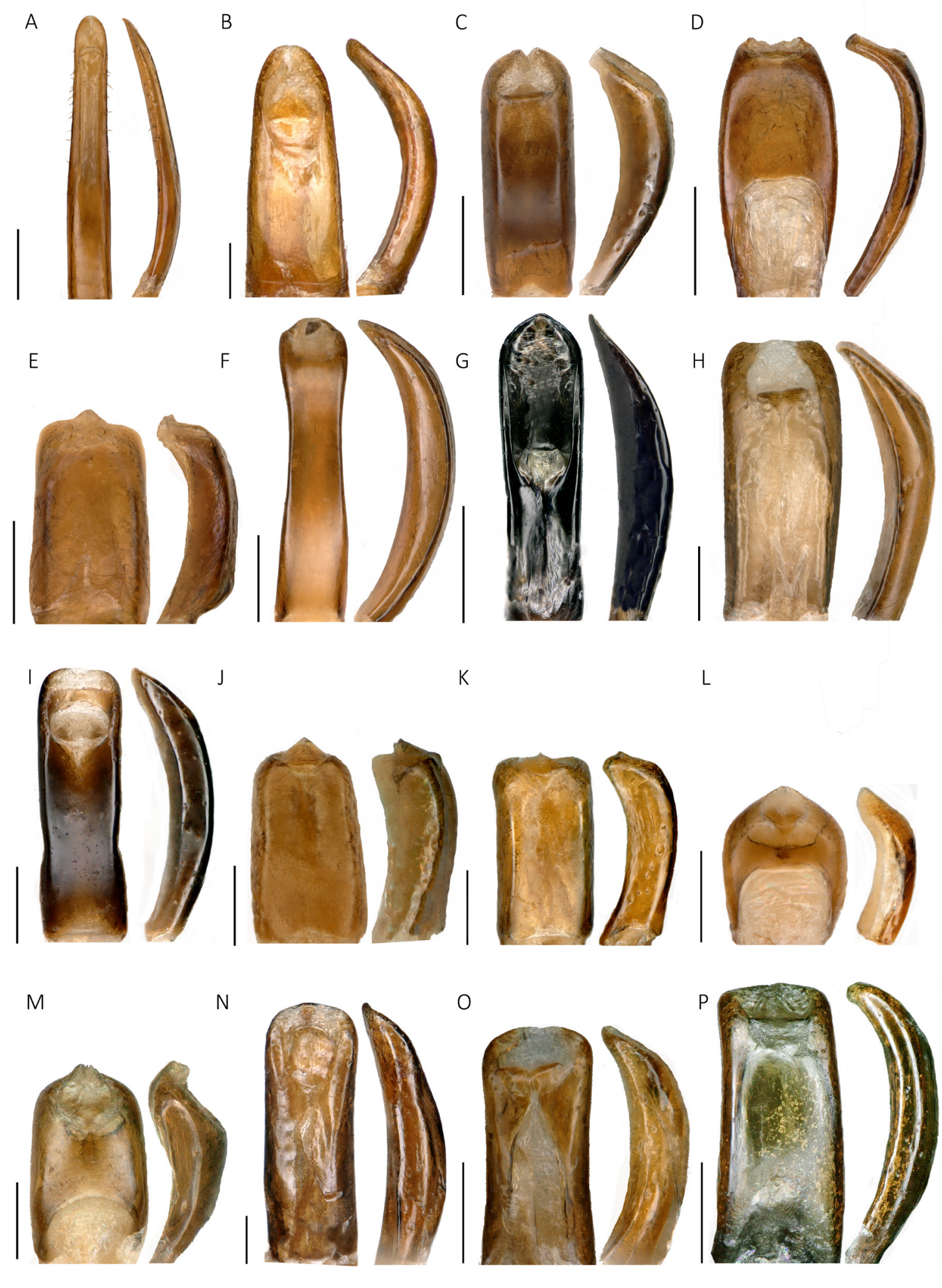

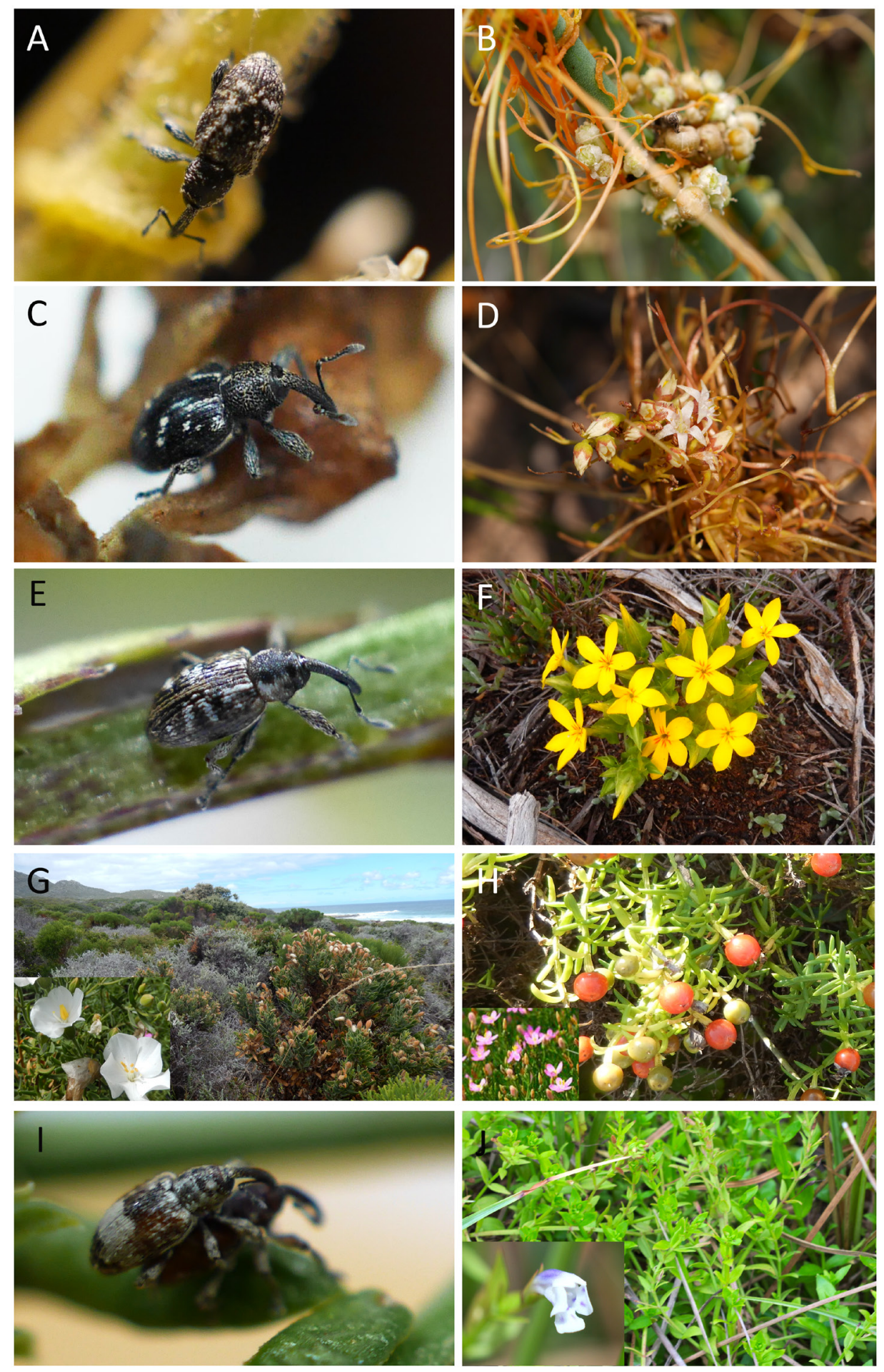

Fig. 6. Habitus in natura, host plants and habitats of Smicronyx of southern Africa. A. S. fallax (Gyllenhal, 1863) on Cuscuta campestris Yunck, 1932. B. Cuscuta campestris. C. S. pseudocoecus sp. nov. on Cuscuta sp. D. Cuscuta nitida E. Mey ex Choisy, host of S. pseudocoecus sp. nov. and S. australis sp. nov. E. S. san sp. nov. on Chironia baccifera L. F. Sebaea Sol. ex R.Br. sp., host of S. san sp. nov. G. Orphium frutescens L. (E. Mey), host of $S$. san sp. nov. and surrounding fynbos vegetation. H. Chironia baccifera, host of S. san sp. nov. I. S. zonatus Haran, 2018, in copula. J. Orobanchaceae Vent., host of $S$. zonatus growing in a marshy environment at the base of Cyperaceae Juss. 


\section{Paratypes}

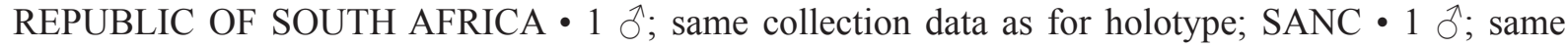
collection data as for holotype; $\mathrm{BMNH} \bullet 1$ त; same collection data as for holotype; MNHN $\bullet 1$; ; same

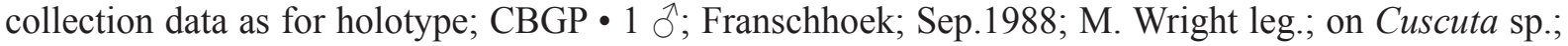
SAMC • 1 q; Kleinmond Nature Reserve; 34.20.00 S, 18.58.92 E; 22 Nov. 2007; E. Colonnelli leg.; MCZ • 1 đ; Cape Town; 1886; J.C. Purcell leg.; SAMC SAM-COL-A073096 • 1 đ;; Tulbagh; 27 Jan. 2019; J. Haran leg.; beating dry Cuscuta sp.; JHAR02116; CBGP • 5 specs; Malmesbury; 33²9'15.9" S 1840'09.3" E; 10 Sept. 2019; J. Haran leg.; beating Cuscuta nitida; JHAR00782_02; ethanol coll. CBGP • 1 ○े, 14 specs; Geko Creek Lodge; 32²3'41.03" S 1859'12.12" E; 2 Nov. 2019; J. Haran leg.; beating Cuscuta sp.; JHAR03018; ethanol coll. CBGP.

\section{Description}

Body Length. $1.8-2.0 \mathrm{~mm}$.

Colour. Body integument entirely black, shiny, mostly bare of scales; vestiture of elytra consisting of white recumbent, elliptical, scales twice as long as wide, grouped in ill-defined transverse bands, a spot on humeri and a longitudinal strip at base of interstria 3; each interstria with series of recumbent, white setae.

HEAD. Rostrum slightly longer than head + prothorax in lateral view, strongly downcurved in basal half, less downcurved in apical half (Fig. $3 \mathrm{H}$ ), dorsal face punctate, covered with suberect whitish setae forming four distinct series in basal $2 / 3$ and two spots near eyes, apical $1 / 3$ glabrous; transverse furrow at base of rostrum shiny, bare of scales; head capsule glabrous; eyes flat, contiguous on ventral side; scape of antennae straight, slightly and regularly widening toward apex, clavate at apical $1 / 3$, segment 1 of funicle elongate, as long as $2+3,4-7 \times$ wider than long.

Prothorax. As long as wide (ratio w/1: 1), widest near middle of length, narrowed at apex, sides rounded; integument punctuate and granulous, punctures forming concentric circles at basal half; scales white, elongate, rare, mostly present along apical margin, and forming a small spot near scutellum.

Elytra. Sides rounded, widest near middle of length (ratio w/1: 0.65); humeri raised; striae narrow, interstriae flat, wide, integument slightly reticulate, apex of interstria 5 lacking declivital callosity; scutellum small, bare of scales.

ABDOMEN. Underside mostly covered with overlapping white scales, more condensed on metanepisterna.

Legs. Covered with whitish semi-erect elongate scales; femora clavate, unarmed; tibiae straight on external side, slightly bisinuate ventrally at basal 1/3; claws slightly unequal in length.

GenitaLia. Body of penis elongate (ratio w/l: 0.28 ), $3 \times$ as long as apodemes, sides sub-parallel, slightly expanding from middle of length to apical $1 / 5$, converging apicad, acuminate at apex, curvature in lateral view moderate and regular, tapering at apex (Fig. 5G).

\section{Sexual dimorphism}

Females are distinguished from males by their rostrum, which is more downcurved in apical half in lateral view, and by the antennal insertion which is near middle of length (near apical $1 / 3$ in males). 


\section{Life history}

Adults of S. pseudocoecus sp. nov. were collected on Cuscuta nitida E. Mey ex Choisy, 1842 (Fig. 6CD) and other unidentified species of Cuscuta. Most Cuscuta sp. are red-listed endangered species in the Republic of South Africa. Adults were collected in January, March, September and November.

\section{Distribution}

Republic of South Africa (Western Cape Province).

Smicronyx paucisquamis sp. nov. urn:1sid:zoobank.org:act:445D4B93-E3FD-4A72-A0E0-81C75252CC47

Figs 1I, 4A, 5H; Table 1

\section{Differential diagnosis}

Smicronyx paucisquamis sp. nov. is closest to $S$. pseudocoecus sp. nov.. See differential diagnosis under that species for diagnostic traits.

\section{Etymology}

Smicronyx paucisquamis sp. nov. is named in reference to the very limited number of scales found on its elytra compared to other species in the genus.

\section{Material examined}

\section{Holotype}

REPUBLIC OF SOUTH AFRICA • 1 §ं; "Rep. of South Africa; Haenertsburg [Limpopo Province]; 2356.361'S 2957.037'E; 1380 m, 7.ii.2019; J. Haran leg." / “On Cuscuta sp.; JHAR02167” / "Holotype; Smicronyx paucisquamis; Haran 2021"; SAMC.

\section{Paratypes}

REPUBLIC OF SOUTH AFRICA • 1 ; ; same collection data as for holotype; ethanol coll. CBGP • 1 ; Mpumalanga Province, God's window; 245․ $396^{\prime}$ S, 3051.650' E; 6 Feb. 2019; J. Haran leg.; beating Cuscuta sp.; JHAR02168; ethanol coll. CBGP.

\section{Description}

Body LENGTH. 2.0-2.2 mm.

CoLour. Body integument entirely black, shiny, mostly bare of scales; vestiture of elytra consisting of white recumbent, elliptical, scales more than twice as long as wide, grouped into spots at base of interstria 3 , basal $1 / 3$ of interstriae $4-5$ and middle of length of interstriae 3-5; each interstria with a series of short, recumbent, white setae.

HEAD. Rostrum as long as head + prothorax in lateral view, downcurved near base, less downcurved in apical half (Fig. 4A); dorsal face punctate, covered with suberect whitish setae forming four distinct series in basal $2 / 3$ and two spots near eyes, apical $1 / 3$ glabrous; transverse furrow at base of rostrum shiny, bare of scales; head capsule glabrous; eyes flat, sub-contiguous on ventral side, space between them wider than the diameter of two ommatidia; scape of antennae slightly bisinuate, regularly widening toward apex, clavate in apical $1 / 3$, segment 1 of funicle elongate, as long as $2+3,4-7$ wider than long.

Prothorax. Isodiametric (ratio w/1: 1), widest near middle of length, narrowed at apex, sides rounded; integument with large punctures, diameter of punctures wider than distance between punctures; scales 
whitish, elongate, semi-erect, not concealing the integument, mostly present at base of median line near scutellum and on sides of prothorax.

ELYTRA. Sides moderately rounded, widest near middle of length (ratio w/l: 0.66); humeri raised; striae narrow, interstriae flat, wide, $4-5 \times$ as wide as striae, integument shiny, slightly reticulate, apex of interstria 5 with a very moderate declivital callosity; scutellum small, covered with short whitish scales.

ABDOMEN. Underside mostly covered with overlapping white scales, more condensed on metanepisterna.

LEGs. Covered with whitish, recumbent, elongate scales; femora clavate, armed with a very small ventral tooth usually concealed by scales; tibiae straight on external side, slightly bisinuate ventrally; claws equal in length.

Genitalia. Body of penis elongate (ratio w/l: 0.44), as long as apodemes, sides sub-parallel, slightly expanding from base to apex, converging near apex, truncate at apex, curvature in lateral view moderate and regular, tapering near apex (Fig. 5H).

\section{Sexual dimorphism}

Females are distinguished from males by their rostrum, which is slightly longer, and covered with scales only in basal $1 / 3$ (in basal $1 / 2$ in males).

\section{Life history}

Adults were found in February on an unidentified Cuscuta sp.

\section{Distribution}

Republic of South Africa (Limpopo and Mpumalanga provinces).

Smicronyx fallax (Gyllenhal, 1863)

Figs 1J, 4B, 5I, 6A; Table 1

Micronyx fallax Gyllenhal, 1836: 427.

Smicronyx fallax (Gyllenhal, 1836) [Schoenherr 1843].

\section{Differential diagnosis}

Of the southern African Smicronychini, Smicronyx fallax is closely related to S. albosquamosus, which may be found in sympatry with this species. They can be distinguished by the shape of their prothorax (isodiametric in S. fallax, wider than long in S. albosquamosus) and their claws (equal in length in S. fallax, unequal in S. albosquamosus in most specimens). These species show an interspecific genetic distance of $12.3 \%$ for the barcode fragment.

\section{Material examined}

Neotype (here designated)

REPUBLIC OF SOUTH AFRICA • 1 đ ; "Rep. of South Africa; Underberg [KwaZulu-Natal Province]; 29³46'37.42"S 29³0'00.44"E; 1579 m, 25.xii.2018; J. Haran leg." / "Beating Cuscuta sp. parasite of Artemisia afra; JHAR01694_0101" / "NeоtYPE; Smicronyx fallax (Gyllenhal, 1836); Des. Haran 2021"; NHRS. 


\section{Other material}

NAMIBIA • 14 specs; Oanob lake; $23^{\circ} 19.242^{\prime}$ S, $17^{\circ} 1.008^{\prime}$ E; 7 Dec. 2018; J. Haran leg.; beating and at base of Cuscuta campestris parasite of Asteraceae; JHAR01630; ethanol coll. CBGP.

REPUBLIC OF SOUTH AFRICA • 1 $\delta$; same collection data as for neotype; SAMC; $\bullet 1 \hat{\delta}$; same collection data as for neotype; SANC $\bullet 1$; same collection data as for neotype; CBGP • 9 specs; same collection data as for neotype; ethanol coll. CBGP 1 1 ${ }^{\lambda}$; Limpopo Province, Tzaneen Mokgolobotho; $23^{\circ} 51.967^{\prime}$ S, 30¹6.776' S; alt. 561 m; 7 Feb. 2019; J. Haran leg.; beating and at base of Cuscuta sp. parasite of Asteraceae; JHAR02166; CBGP • 2 ồ 1 o ; Mpumalanga Province, Kruger Park, Skukuza; 12-14 Dec. 1985; S. \& J. Peck leg.; thorn scrub forest, evening car netting; MCN • 5 ô $\widehat{\partial}, 5$ 우; Kruger National Park, Skukuza; 24.59 S, 3138 E; 8 Mar. 1996; Endrödy-Younga leg.; UV light; TMSA • 8 ठో ठૈ, 6 우우; Kruger National Park, Pafuri rest camp; 22.25 S, 31.12 E; 30 Jan. 1994; Endrödy-Younga leg.; UV light trap; TMSA - 1 क; Limpopo Province, Little Muck; 22.15 S, 29.16 E; 8-9 Dec. 2008; R. Müller leg.; at light; TMSA • 1 §’; Kareepoort, near Sonop; 25.38,3 S, 27.39,4 E; alt. 1150 m; 1 Oct.

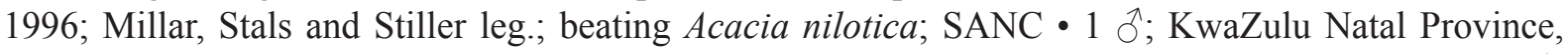
South West Magudu; 27.3 S, 31.35 E; alt. 480 m; 4 Jan. 2009; P. Schüle leg.; light trap; SANC • 1 đ;; Gauteng Province, Rivonia; 23 Oct. 1967; M.I. Russell leg.; BMNH • 1 ð’; Orange Free State, HendrikVerwoeddam, Gariep dam; 30.40' S, 25.30' E; alt. 1300 m; 6 Nov. 1988; E. Colonnelli leg.; MCZ.

ZIMBABWE • 1 ð̊; Matopo, Maleme Dam; 30 Jan. 1963; J. Weir leg.; BMNH.

\section{Redescription}

BoDy LENGTH. 2.0-2.1 mm.

Colour. Body integument entirely black, shiny; vestiture of elytra consisting of whitish and brownish, recumbent, elliptical scales, twice as long as wide; whitish scales forming two ill-defined, oblique bands from humeri to apical $2 / 3$ of elytral suture and a spot on declivital callosities.

HEAD. Rostrum longer than head + prothorax in lateral view, almost straight (Fig. 4B), dorsal face punctate, covered with suberect whitish scales forming four distinct series in basal $2 / 3$ and two spots near eyes, apical $1 / 3$ bearing scattered white setae; transverse furrow at base of rostrum shiny, bare of scales; head capsule glabrous; eyes flat, sub-contiguous on ventral side; scape of antennae slightly bisinuate, slightly and regularly widening toward apex, not clavate at apex, segment 1 of funicle elongate, longer than $2+3,2$ square, $3-7$ wider than long.

Prothorax. Isodiametric (ratio w/l: 1), widest near middle of length, sides moderately rounded, not greatly narrowed at apex; integument punctuate and granulous, punctures forming weak concentric circles in basal 1/2; scales whitish and brownish, elongate, mostly condensed along the median line and on the sides.

ELYTRA. Sides subparallel in basal $2 / 3$ of length, rounded in apical $1 / 3$, widest near middle of length (ratio w/1: 0.70); humeri raised; striae narrow, interstriae flat, wide, $4 \times$ as wide as striae, integument shiny, slightly reticulate, apex of interstria 5 with a very slight declivital callosity; scutellum small, bare of scales.

AвDomen. Underside mostly covered with non-overlapping greyish scales, not condensed on metanepisterna.

LeGs. Covered with whitish, semi-erect, elongate scales; femora clavate, armed with a tiny ventral tooth, usually concealed with scales; tibiae straight on external side, slightly bisinuate ventrally; claws equal in 
length. Genitalia. Body of penis elongate (ratio w/l: 0.33), $1.3 \times$ as long as apodemes, sides sub-parallel, broadly rounded at apex, curvature in lateral view moderate and regular, tapering at apex (Fig. 5I).

\section{Sexual dimorphism}

Females are distinguished from males by their rostrum, which is slightly longer, and covered with scales only in basal $1 / 4$ (in basal $1 / 3$ in males).

\section{Life history}

All recently collected specimens of this species were found on dodders (Cuscuta spp.) including the introduced weed Cuscuta campestris Yunck, 1932 (Fig. 6A-B). Labels indicate that this species might be collected with light traps (UV light). Adults were collected from October to March.

\section{Distribution}

Smicronyx fallax is widely distributed in the subtropical and desert areas of southern Africa. It has been recorded from Namibia to Zimbabwe, and in the Gauteng, KwaZulu-Natal, Limpopo, Mpumalanga and Orange provinces of the Republic of South Africa.

\section{Remarks}

The type specimen of $S$. fallax was deposited by Gyllenhal in the collection of Ecklon \& Zeyer (Gyllenhal 1836), currently lost. In the absence of further information about this type, and in order to stabilize the taxonomy in this genus, a neotype was designated based on the description of this species. Gyllenhal described $S$. fallax as a species very closely related to the Palaearctic taxon $S$. jungermanniae Reich, 1797. This description corresponded very well to the specimens used to re-describe this species, both regarding external and internal morphology. In addition, COI sequences obtained from these specimens (JHAR01630_0101-1694_0101 [GB accession: MT370316-17]) showed that they are closest to $S$. jungermanniae out of all the species of Smicronyx for which a barcode sequence is available (uncorrected p-distance of 7.0\%). The neotype (here designated) was designated for a male specimen from a population from the western side of KwaZulu-Natal Province in the Republic of South Africa, which is close to the original type locality of $S$. fallax ("Caffraria", probably corresponding to the Eastern Cape Province). Three male and nine unsexed specimens stored in ethanol from this series were deposited in the institutions CBGP, SAMC and SANC.

Smicronyx australis sp. nov.

urn:lsid:zoobank.org:act:11BB79AF-69BD-4596-B063-01C2E7782E04

Figs $1 \mathrm{~K}, 4 \mathrm{C}$, 5J; Table 1

\section{Differential diagnosis}

Smicronyx australis sp. nov. is closest to $S$. pauperculus, a species widely distributed in the Mediterranean region and in Africa, including the Republic of South Africa. The two species can be distinguished by the colour of their integument (elytra black in S. australis sp. nov., at least partly red in S. pauperculus). The sequences of COI of $S$. australis sp. nov. (GB accession: MT370318) showed an interspecific p-distance of 3\% with specimens of S. pauperculus from the Near East and Canary Islands (Genbank accessions: KU942318 and KU942313, respectively).

\section{Etymology}

Smicronyx australis sp. nov. is named in reference to the southern distribution of this species, compared to the wide distribution of its neighbour species S. pauperculus. 


\section{Material examined}

\section{Holotype}

REPUBLIC OF SOUTHAFRICA • 1 đo; "Rep. of South Africa; Stellenbosch Mt. [Western Cape Province]; 3357'09.41S, 1853'14.09E; 539 m, 4.x.2018; J. Haran leg." / "Sweeping fynbos; JHAR01557_0101" / "Holotype; Smicronyx australis; Haran 2021"; SAMC.

\section{Paratypes}

REPUBLIC OF SOUTH AFRICA - 1 ơ; Western Cape Province, Malmesbury; 33.486789 S, 18.669325 E; 10 Sep. 2019; J. Haran leg.; beating Cuscuta nitida; JHAR03005; SAMC • 1 क; same collection data as for preceding; JHAR03005; CBGP・1 ${ }^{\text {}}, 1$ \% ; 7-20 km North of Citrusdal; $32.25 .67 \mathrm{~S}$,

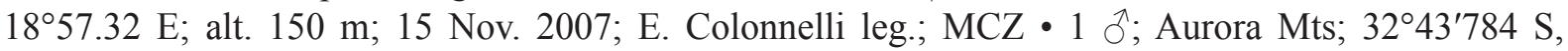
18.34.5889 E; alt. 850 m; 9 Sept. 2013; R. Borovec leg.; beating fynbos; FFWS • 1 \%; Boschendal Wine estate; $33^{\circ} 53.955^{\prime} \mathrm{S}, 18^{\circ} 59.651^{\prime}$ E; alt. 354 m; 16 Aug. 2019; J. Haran leg.; beating fynbos; ethanol coll.

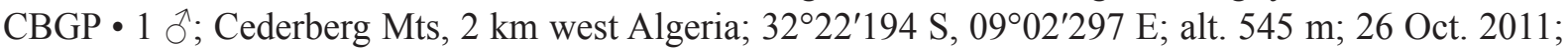
R. Borovec leg.; sweeping; FFWS • 1 ô, mounted; Geko Creek Lodge; 32.381182 S, 18.993322 E; 2 Nov. 2019; J. Haran leg.; beating Cuscuta sp.; JHAR03017; ethanol coll. CBGP • 30 specs; same collection data as for preceding; JHAR03017; ethanol coll. CBGP • 1 đo; Groenfontein; $33^{\circ} 51.105^{\prime}$ S,

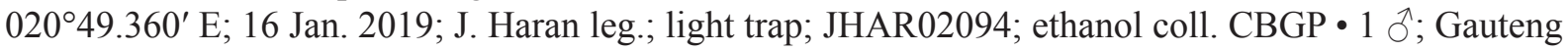
Province, Roodeplaat Dam Nature Reserve; 25.41 S, 28.18 E; 22 Feb. 1988; I.M. Millar leg.; SANC.

\section{Description}

Body LeNGTH. 1.9-2.0 mm.

Colour. Body integument entirely black, shiny, femora and tibiae reddish in middle; vestiture of elytra consisting of whitish and brownish recumbent elliptical scales, more than twice as long as wide; whitish scales forming ill-defined transverse bands and a spot on prothorax and elytra near scutellum.

HEAD. Rostrum as long as head capsule + prothorax in lateral view, moderately downcurved (Fig. 4C); dorsal face weakly punctate, covered with suberect whitish scales forming 4 more-or-less distinct series in basal $2 / 3\left(\delta^{\Uparrow}\right)$ or $1 / 3(+9)$, more condensed near eyes, apical $1 / 3$ bearing scattered white setae; transverse furrow at base of rostrum shiny, bare of scales; head capsule glabrous; eyes flat, sub-contiguous on ventral side, separated by a distance as wide as the width of 1 ommatidium; scape of antennae very slightly bisinuate, regularly widening toward apex, clavate at apex, segment 1 of funicle elongate, slightly longer than $2+3$, segments $2-7$ transverse, segment 7 more than twice as wide as long.

Prothorax. Isodiametric (ratio w/l: 1), widest slightly before middle of length, sides moderately rounded, narrowed at apex; integument punctuate and granulous; scales whitish and brownish, elongate, mostly oriented toward the median line.

ELYTRA. Sides subparallel in basal $2 / 3$, rounded in apical 1/3, widest near middle of length (ratio w/1: 0.70); humeri raised; striae narrow, interstriae flat, $3-4 \times$ as wide as striae, integument slightly reticulate, apex of interstria 5 with a very moderate callosity; scutellum small, bare of scales.

ABDOMEN. Underside mostly covered with non-overlapping whitish scales, not condensed on metanepisterna.

Legs. Covered with whitish semi-erect elongate scales; femora clavate, bearing a minute ventral tooth usually hidden by scales; tibiae straight on external side, slightly bisinuate ventrally at basal third; claws equal in length. 
Genitalia. Body of penis short (ratio w/1: 0.60 ), $0.6 \times$ as long as apodemes, sides sub-parallel or slightly expanding apicad, apex truncate, curvature in lateral view moderate and regular (Fig. 5J); endophallus sclerified, forming longitudinal striae at base of body in dorsal view.

\section{Sexual dimorphism}

Females are distinguished from males by their rostrum, which is slightly longer, and covered with scales only in basal $1 / 3$ (in basal $2 / 3$ in males).

\section{Life history}

This species was collected on stems and flowers of Cuscuta nitida (Fig. 6D) and other Cuscuta spp. Adult specimens were also collected by light trap and by beating fynbos bushes. Adult collection times ranged from August to February.

\section{Distribution}

This species is distributed in the Gauteng and Western Cape provinces of the Republic of South Africa.

\section{Remarks}

Slight differences in the external and internal morphology and the genetic distances between these species enabled $S$. australis sp. nov. to be distinguished as a distinct species. The black specimens of S. pauperculus reported previously (Haran 2018) correspond to S. australis sp. nov.

\section{Smicronyx pauperculus Wollaston, 1864}

Figs $1 \mathrm{~L}, 5 \mathrm{~K}$; Table 1

Smicronyx pauperculus Wollaston, 1864: 317.

\section{Differential diagnosis}

Of the southern African Smicronychini, S. pauperculus can be distinguished by the red colour of integuments and the absence of a wide transverse band on its elytra.

\section{Material examined}

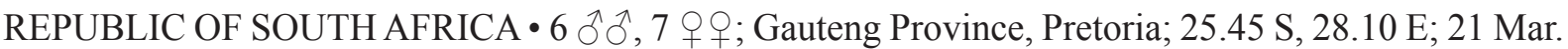

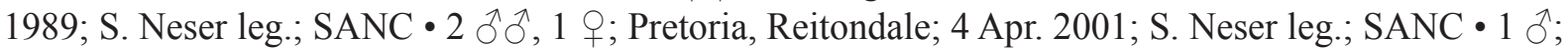
Kruger National Park, Pafuri rest camp; 22.25 S, 31.12 E; 30 Jan. 1994; Endrödy-Younga leg.; UV light trap; TMSA • 4 specs; Mpumalanga Province, God's Window; 245․ $546^{\prime}$ S, $30^{\circ} 51.650^{\prime}$ E; alt. 1494 m; 6 Feb. 2019; J. Haran leg.; beating Cuscuta sp.; JHAR02130; ethanol coll. CBGP.

NAMIBIA • 1 §ं; Weldevrede Guest Farm; 24.10 S, 15.58 E; alt. 1105 m; 11-13 Feb. 2010; R. Müller leg.; at light; TMSA.

\section{Lectotype}

See Haran (2018).

\section{Diagnosis}

BODY LENGTH. 1.9-2.0 mm.

Colour. Body integument reddish, except rostrum, antennae, prothorax, suture of elytra and tarsi, which are usually black; vestiture of elytra generally consisting of elongate brownish scales, recumbent, not concealing integument, and whitish scales, thicker, forming transverse patches. 
HEAD. Rostrum moderately and regularly downcurved in lateral view, longer than head capsule + prothorax.

Prothorax. Isodiametric (w/l ratio: 1), sides rounded in basal half, constricted apically, widest slightly behind middle, with median line of whitish scales, mostly visible near scutellum.

ELYTRA. Subparallel in basal two thirds (w/l ratio: 0.65), rounded toward apex in apical third.

Legs. Femora moderately clavate, armed with a small but distinct ventral tooth, tibiae straight; claws equal in length.

Genitalia. Body of penis moderately elongate (w/1 ratio: 0.60 ), $0.6 \times$ as long as apodemes, sides straight, subparallel, apex truncate, moderately and regularly curved in lateral view (Fig. 5K); endophallus slightly sclerified, not forming any longitudinal striae at base of body in dorsal view.

\section{Life history}

This species is known to feed on flowers of Cuscuta campestris (Anderson 1974; Haran et al. 2017) developing on plants of open and disturbed agricultural areas. It is often recorded by light trapping. In sub-Saharan Africa, adults were collected almost all year round (February-May, July-September, November-December).

\section{Distribution}

Smicronyx pauperculus is widely distributed in the Mediterranean region (Caldara 2013; Haran et al. 2017). In sub-Saharan Africa, it has been recorded in West (Mali) and East Africa (Kenya, Tanzania) (Haran 2018) and is newly reported here from southern Africa (Republic of South Africa [Gauteng and Limpopo and Mpumalanga provinces] and Namibia).

\section{Remarks}

The identity of this species was established based on the examination of the lectotype as reported by Haran (2018). In southern Africa, this species is closest to its sister species $S$. australis sp. nov.; see differential diagnosis and remark sections on that species for diagnostic traits.

Smicronyx san sp. nov. urn:lsid:zoobank.org:act:F652DB37-9106-483C-A89F-9F2375C52910

Figs 2A-C, 4D, 5L, 6E; Table 1

\section{Differential diagnosis}

In the Republic of South Africa, S. san sp. nov. is closest to S. drakensbergensis sp. nov.; it can be distinguished from this species by the coating on the elytra (white and brown scales, grey in $S$. drakensbergensis sp. nov.), the ratio of its prothorax (isodiametric, slightly longer than wide in S. drakensbergensis sp. nov.), and its shorter penis body (Fig. 5L-M).

\section{Etymology}

This species is dedicated to the San people, hunter gatherers whose first traces date back 44000 years in southern Africa. They left remarkable marks of their presence along the coast in Western Cape Province, where $S$. san sp. nov. forms dense populations due to the local abundance of its host plants. 


\section{Material examined}

Holotype

REPUBLIC OF SOUTH AFRICA • 1 đ; ; "Rep. of South Africa; Stellenbosch [Western Cape Province]; 3356.566S, $18^{\circ} 52.402 \mathrm{E} ; 156 \mathrm{~m}, 20.1 i .2018$; J. Haran leg." / “on Chironia baccifera; JHAR00761_0101” / "Holotype; Smicronyx san; Haran 2021"; SAMC.

\section{Paratypes}

REPUBLIC OF SOUTH AFRICA $\bullet 1 \hat{\partial}, 1$; same collection data as for holotype; BMNH $\bullet 2 \hat{\delta}$, 2 ㅇ; same collection data as for holotype; $\mathrm{CBGP} \bullet 1 \hat{\jmath}, 1$; ; same collection data as for holotype;

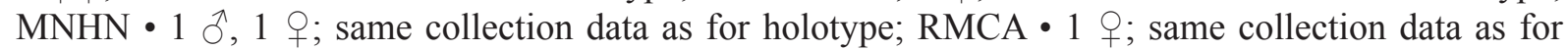
holotype; SAMC $\bullet 1$ ô, 1 q; same collection data as for holotype; SANC $\bullet 6 \hat{\jmath}, 7$ $q$; ; Western Cape Province, Cape Peninsula; 34²0.300 S, $18^{\circ} 27.489$ E; alt. 16 m; 24 Feb. 2018; J. Haran leg.; on Orphium frutescens; JHAR00769; CBGP • 4 specs; Stellenbosch, Bottelaryberg; 29 Jun. 2019; J. Haran leg.; on Chironia baccifera; JHAR02343; ethanol coll. CBGP • 14 specs; Helderberg; $34^{\circ} 0.88^{\prime} \mathrm{S}, 18^{\circ} 53.533^{\prime} \mathrm{E}$; alt. 443 m; 19 Aug. 2018; J. Haran leg.; on Sebaea sp.; JHAR01367; ethanol coll. CBGP • 1 ภ, 1 क; Kapstyl; 24 Aug. 2018; J. Haran leg.; on Chironia baccifera; JHAR01438; CMNC • 20 specs; same collection data as for preceding; JHAR01438; ethanol coll. CBGP・ 1 ठ , 2 q $O$; Western Cape Province, R27 near Langebaan; $33^{\circ} 06.04$ S, $18^{\circ} 07.71$ E; 14 Nov. 2007; E. Colonnelli leg.; MCZ • 7 specs; Gansbaai, Grootbos private nature reserve; 11 Aug. 2018; J. Haran leg., on Chironia sp.; JHAR01317; ethanol coll.

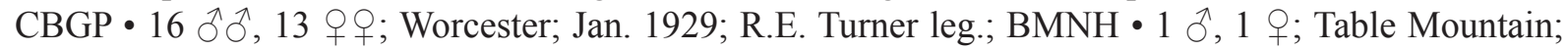
1906; W. Bevins leg.; BMNH • 1 क; Cape Town, Milnerton; 14-28 Dec. 1925; R.E. Turner leg.; BMNH - 1 O; Swellendam; 17 Dec. 1931-18 Jan. 1932; R.E. Turner leg.; BMNH • 4 specs; Somerset West, Helderberg Nature Reserve; 34.062212 S, 18.873992 E; 14 Oct. 2019; J. Haran leg.; sweeping Sebaea aurea; JHAR01367_02; ethanol coll. CBGP.

\section{Description}

Body LeNGTH. 1.8-2.0 mm.

Colour. Body integument entirely black, shiny; vestiture of elytra consisting of recumbent, elliptical, twice as long as wide, overlapping scales, pale brown with transverse shades of white scales, densely covering but not concealing the integument.

HEAD. Rostrum as long as head + prothorax in lateral view, moderately and regularly downcurved (Fig. 4D), in dorsal view punctate, covered with suberect brown scales in basal $1 / 3-1 / 2$, glabrous in apical half; transverse furrow at base of rostrum shiny, bare of scales; head capsule glabrous; eyes flat, close to each other on ventral side, separated by a distance equal to width of 2-3 ommatidia; scape of antennae straight, slightly and regularly widening apicad, clavate in apical $1 / 3$, segment 1 of funicle elongate, as long as $2+3,4-7$ wider than long.

Prothorax. Isodiametric (ratio w/l: 1), widest near middle of length, narrowed at apex, sides rounded; integument greatly punctuate and granulous, shiny; scales pale brown, overlapping, usually concentrated on sides, with a spot of white scales near humeri; disc usually bare of scales or with narrow scales not concealing integument, forming a broad longitudinal strip where integument remains visible; median line sometimes bearing a narrow band of brown scales, generally visible at base near scutellum.

ELYTRA. Sides rounded, widest near middle of length (ratio w/1: 0.76); humeri raised; striae narrow, interstriae flat, wide, integument slightly reticulate, apex of interstria 5 lacking declivital callosity; scutellum small, not visible through coating. 
AвDOMEN. Underside mostly covered with overlapping pale brown scales, more condensed on metasternum and metanepisterna.

LEGs. Covered with pale brown semi-erect elongate scales; femora clavate, bearing a tiny ventral tooth usually concealed by scales; tibiae straight on external side, slightly bisinuate ventrally at basal third; claws equal in length.

Genitalia. Body of penis very short (ratio w/l: 1 ), $0.8 \times$ as long as apodemes, sides sub-parallel or slightly expanding from base to apex in basal $2 / 3$, converging in apical $1 / 3$, acuminate at apex, curvature in lateral view regular (Fig. 5L).

\section{Sexual dimorphism}

Females are distinguished from males by their rostrum, which is slightly longer, and less densely covered with scales in basal $1 / 2$.

\section{Life history}

Smicronyx san sp. nov. develops on various Gentianaceae: Chironia baccifera Linnaeus, 1753, Orphium frustescens (L) E. Mey., 1838, Sebaea spp. including S. aurea (L. f.) Roem. \& Schult. (Fig. 6E-H). Adults were collected on the ground under its host plant or by beating the plant in February, June, August, October-December.

\section{Distribution}

Republic of South Africa (Western Cape Province).

\section{Remarks}

Smicronyx san sp. nov. belongs morphologically to the S. reichi (Gyllenhal, 1835) species group (Dieckmann 1990), which is associated with Gentianaceae, and shows a much shorter body of the penis than other Smicronyx species (Pericart 1957). S. san sp. nov. is a polymorphic species, specimens obtained from Orphium frustescens (Fig. 2B) are larger and have a less dense coating than specimens developing on Chironia (Fig. 2A). Specimens obtained from Sebaea have a more elongate body (Fig. 2C) than those on Chironia. However, the sequences of the gene COI revealed no genetic divergence between populations from each host plant.

Smicronyx drakensbergensis sp. nov. urn:1sid:zoobank.org:act:0E52BFCE-0C56-411D-A089-EA48704B33C2

Figs 2D, 4E, 5M; Table 1

\section{Differential diagnosis}

Smicronyx drakensbergensis sp. nov. belongs to the species group of S. reichi and is morphologically closest to $S$. san sp. nov. in southern Africa. See diagnosis and remark sections under that species for diagnostic traits.

\section{Etymology}

This species is named in reference to the mountain range where the type series was collected. 


\section{Material examined}

Holotype

REPUBLIC OF SOUTH AFRICA • 1 ơ; "S. Afr.; Drakensberg [KwaZulu-Natal Province]; Cathedral PkRainbowG [gorges]; 28.57S 29.14E” / "17.i.1997; E-Y; 3257; grassnetting; leg. Endrödy-Younga" / "HoLOTYPE; Smicronyx drakensbergensis; Haran 2021"; TMSA.

\section{Paratype}

REPUBLIC OF SOUTH AFRICA • 1 đ; same collection data as for holotype; SAMC.

\section{Description (ठ)}

Body LENGTH. 2.0-2.2 mm.

CoLour. Body integument entirely black, shiny; vestiture of elytra consisting of recumbent, elliptical or rounded, brownish and whitish, overlapping scales, densely covering but not concealing the integument.

HEAD. Rostrum as long as head + prothorax in lateral view, moderately and regularly downcurved (Fig. 3E), in dorsal view punctate, covered with suberect whitish scales in basal 1/2, glabrous in apical 1/2; transverse furrow at base of rostrum shiny, bare of scales, with two spots of white erect scales on each side near eyes; head capsule glabrous; eyes flat, close to each other on ventral side, separated by width of 2-3 ommatidia; scape of antennae straight, slightly and regularly widening toward apex, clavate in apical $1 / 3$, segment 1 of funicle elongate, slightly longer than $2+3,4-7$ wider than long.

Prothorax. Wider than long (ratio w/l: 1.07), widest before middle of length, narrowed at apex, sides moderately rounded; integument greatly punctuate and granulous, shiny; scales greyish, overlapping, not concealing integument.

ELYTRA. Sides rounded, widest near middle of length (ratio w/1: 0.73); humeri raised; striae narrow, $1 / 2-1 / 3$ as wide as interstriae, interstriae flat, wide, integument shiny, slightly reticulate, apex of interstria 5 with very small declivital callosity; scutellum small, not visible through coating.

ABDOMEN. Underside mostly covered with overlapping greyish scales, more condensed on metasternum and metanepisterna.

Legs. Covered with pale brown and greyish semi-erect, elongate scales; femora clavate, bearing a tiny ventral tooth usually concealed by scales; tibiae straight on external side, slightly bisinuate ventrally at basal third; claws equal in length.

Genitalia. Body of penis short (ratio w/l: 0.80 ), $2.2 \times$ shorter than apodemes, sides sub-parallel, apex acuminate, curvature in lateral view regular (Fig. 5M). Female unknown.

\section{Life history}

Host plant unknown. Adults were collected in January.

\section{Distribution}

Republic of South Africa (KwaZulu-Natal Province). 
Smicronyx zonatus Haran, 2018

Figs 2E, 5N; Table 1

Smicronyx zonatus Haran, 2018: 280.

\section{Differential diagnosis}

Of the African Smicronychini, S. zonatus can be easily distinguished from other species by its reddish integument and its white transverse band on the elytra (Haran, 2018).

\section{Material examined}

REPUBLIC OF SOUTH AFRICA - 1 ; Mpumalanga Province, Kruger National Park, Skukuza Reserve Camp; 24.59 S, 31.35 E; 1 Mar. 1995; Endrödy-Younga leg.; UV light trap; SANC • 1 ð, 1 क; KwaZulu-Natal, Eshowe; Jul. 1926; R.E. Turner leg.; BMNH • 1 गे; Drakensberg, Van Reenen; 1-22 Jan. 1927; R.E. Turner leg.; BMNH.

\section{Other material}

See Haran (2018).

ZAMBIA • 1 §̊; Liua Plains; 29 Nov. 2003; Deschodt and Groenewald leg.; at light; SANC.

\section{Diagnosis}

BODY LENGTH. 2.0-2.5 mm.

CoLour. Body integument reddish, except rostrum, antennae, prothorax, suture of elytra and tarsi, which are usually black; vestiture of elytra generally consisting of elliptical, rounded scales or slightly longer than wide, recumbent, overlapping and almost concealing integument; scales brown with patches of white and a few black spots along the basal half of interstriae 1-3, and a large transverse white band between middle of elytra length and apical 1/4.

HEAD. Rostrum as long as head capsule + prothorax in lateral view, greatly downcurved

Prothorax. Wider than long (w/l ratio: 1.08), sides rounded, widest slightly before middle of length.

ELYTRA. Subparallel in basal $1 / 2$, rounded in apical $1 \frac{1}{2}$ (w/1 ratio: 0.73$)$.

LEGS. Femora and tibiae covered with whitish and pale brown semi-erect, elongate scales; femora greatly clavate, armed with a small but distinct ventral tooth.

Genitalia. Body of penis elongate (w/l ratio: 0.37$), 1.5 \times$ longer than apodemes, subparallel, rounded at apex, in lateral view regularly narrowing from base to apex (Fig. $5 \mathrm{~N}$ ).

\section{Life history}

Recently collected specimens from the Republic of South Africa (Stellenbosch, Western Cape Province) were found on a small unidentified Orobanchaceae (near the genus Euphrasia Linnaeus, 1753), a hemiparasite of Cyperaceae found at low elevation in wet areas near ponds (Fig. 6I-J). Adults were collected in January-March, May, July and November.

\section{Distribution}

Democratic Republic of Congo, Liberia, Republic of South Africa (KwaZulu-Natal, Mpumalanga and Western Cape provinces), Zambia (Haran 2018). 
Smicronyx lutulentus Dietz, 1894

Figs 2F, 4F, 5O; Table 1

Smicronyx lutulentus Dietz, 1894: 170.

\section{Differential diagnosis}

Smicronyx lutulentus is morphologically similar to $S$. fallax and $S$. albosquamosus. It can be distinguished from these species by its elytra pattern, bearing broad and rounded scales, and its short penis body.

\section{Material examined}

REPUBLIC OF SOUTH AFRICA • 6 specs; KwaZulu-Natal Province, Umhlanga; 12 Apr. 2018; population bred at SASRI on Parthenium hysterophorus; JHAR00911; ethanol coll. CBGP.

\section{Diagnosis}

Body LENGTH. 1.6-2.0 mm.

CoLour. Body integument black, rostrum black or dark brown, antennae and tarsi dark brown; vestiture of elytra generally consisting of rounded, grey-brown scales, isodiametric or slightly longer than wide, with a few scattered white scales; white scales concentrated on humeri, on sides and at base of median line near scutellum on prothorax.

HEAD. Rostrum in lateral view downcurved at base and almost straight over the rest of length; slightly longer than head capsule + prothorax.

Prothorax. Isodiametric (w/1 ratio: 1), sides slightly rounded in basal $2 / 3$, constricted apically, widest slightly behind middle of length.

ELYTRA. Subparallel in basal two thirds (w/1 ratio: 0.70), rounded toward apex in apical third.

LEGS. Femora moderately clavate, unarmed, tibiae straight.

Genitalia. Body of penis moderately elongate (w/1 ratio: 0.43 ), as long as apodemes, sides straight, subparallel, moderately and regularly curved in lateral view (Fig. 5O).

\section{Life history}

Smicronyx lutulentus develops in the seeds of the capsules of Parthenium hysterophorus L. (Asteraceae; Dhileepan et al. 1996).

\section{Distribution}

United States of America (Texas; Anderson 1962); introduced as a biocontrol agent of Parthenium in Australia (Dhileepan et al. 1996) and in the Republic of South Africa (KwaZulu-Natal Province; Strathie et al. 2011). 
Smicronyx albosquamosus Wollaston, 1854

Fig. 2G; Table 1

Smicronyx albosquamosus Wollaston, 1854: 345.

\section{Differential diagnosis}

In southern Africa, S. albosquamosus is closest to $S$. fallax. See differential diagnosis section under this species for distinguishing traits.

\section{Material examined}

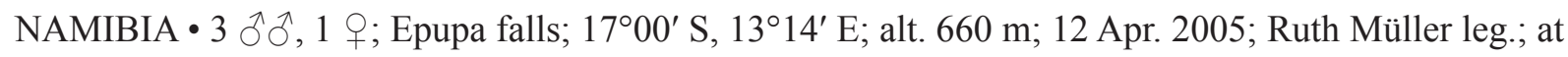
light; TMSA.

REPUBLIC OF SOUTH AFRICA • 1 त, 1 q; Gauteng Province, Roodeplaat Dam Nature Reserve;

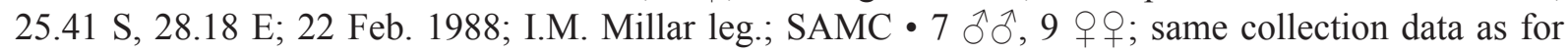
preceding; 26.08 S, 27.50 E; 8 Jan. 1990; S. Neser leg.; with pods and flowers of Cuscuta probably

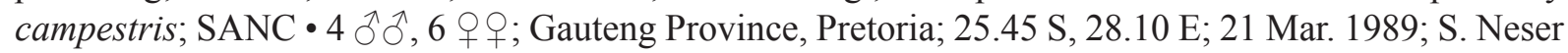
leg.; ex. fruits of Cuscuta sp.; SANC • 1 J, 2 q 9 ; Britstown CP; 30.35 S, 23.30 E; 9 Mar. 1989; S.

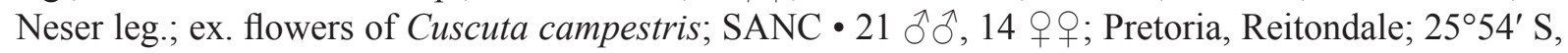
$28^{\circ} 12^{\prime}$ E; 13 Feb. 2006; S. Neser leg.; from flowering and fruiting shoots of Cuscuta sp. Convolvulaceae; SANC • 1 đ ; Limpopo Province, Soutpans; 22.57 S, 29.17 E; alt. 1100 m; 27-30 Mar. 2008; Martin Krüker leg.; TMSA • 1 q; Limpopo Province, Meletse Reserve, Mamba Dam; 24.36 S, 39.13 E; Dec. 2015; E. Seamark leg.; TMSA • 1 § , 5 우; Kruger National Park, Skukuza rest camp; 24.59 S, 31.38 E; 23 Jan. 1995-7 Mar. 1996; Endrödy-Younga and C.L. Bellamy leg.; UV light collection; TMSA • 1 ㅇ; Kwazulu-Natal Province, Ntinini Nature Reserve; 28 $8^{\circ} 7^{\prime \prime}$ S, 3056' E; alt. 1025 m; 17 Nov. 2010; R. Stals leg.; rocky outcrop with trees; SANC $\bullet 2$ 우 ; Mpumalanga Province, Lake Chrissie Farm, 5 km SE Chrissiesmeer; $26^{\circ} 18^{\prime}$ S, $30^{\circ} 15^{\prime}$ E; alt. 1700 m; 25 Nov. 2002; E. Grobbelaar leg.; SANC.

\section{Diagnosis}

Body LeNGTH. 2.0-2.1 mm.

CoLour. Body integument black; vestiture of elytra consisting of recumbent, slightly overlapping brown scales, slightly longer than wide, concealing integument, and white scales usually forming a pale oblique band between humeri and apical third of elytral suture.

HEAD. Rostrum moderately downcurved in lateral view, as long as head capsule + prothorax.

Prothorax. Slightly wider than long (w/1 ratio: 1.15 ), sides moderately rounded in basal $2 / 3$, constricted in apical $1 / 3$, with spots of whitish scales near humeri and at base near scutellum.

ELYTRA. Subparallel in basal two-thirds (w/1 ratio: 0.65), rounded toward apex in apical third.

LEGS. Covered with white and brown scales; femora moderately clavate, armed with small but distinct ventral tooth, tibiae straight; claws unequal in length, at least for fore tarsi.

Genitalia. Body of penis elongate (w/1 ratio: 0.30$), 1.2 \times$ as long as apodemes, sides straight, subparallel, converging near apex; curvature moderate in lateral view (Fig. $5 \mathrm{H})$. 


\section{Life history}

Smicronyx albosquamosus is found across its distribution range on pods and flowers of Cuscuta spp. Adults were collected in southern Africa from November to April.

\section{Distribution}

This species is widely distributed across Africa and the Mediterranean region. In the Republic of South Africa, this species is only found in subtropical areas (Gauteng, KwaZulu-Natal, Limpopo and Mpumalanga provinces)

\section{Remark}

The identity of this species was established by comparisons of specimens with reference material from the Mediterranean region reported by Haran et al. (2017).

Smicronyx namibicus Haran, 2018

Figs 2H, 5P; Table 1

Smicronyx namibicus Haran, 2018: 282.

\section{Differential diagnosis}

Of the African Smicronychini, Smicronyx namibicus can distinguished by the scales on elytra forming a contrasting black square on basal half of interstriae 1-4, surrounded with white scales (Haran 2018).

\section{Material examined}

REPUBLIC OF SOUTH AFRICA • 1 đ ; Kwazulu-Natal Province, Escourt; 4 Jan. 1899; G.A.K. Marshall leg.; BMNH.

\section{Other material (holotype)}

See Haran (2018).

\section{Diagnosis}

Body LENGTH. 2.0-3.0 mm.

CoLour. Body integument black, antennae, femora and tibiae dark reddish; vestiture of elytra generally consisting of recumbent, rounded or slightly longer than wide scales, forming a dark-brown square in basal half and between interstriae 5 of each elytron; rest of scales on elytra greyish to brown, paler near dark-brown square; vestiture of prothorax consisting of brownish scales, with 5 longitudinal whitish stripes.

HEAD. Rostrum slightly longer than head capsule + prothorax in lateral view, moderately downcurved, curvature stronger near base and near antennal insertion.

Prothorax. Slightly wider than long (w/1 ratio: 1.06), widest before middle of length, sides greatly rounded in basal $2 / 3$.

ELYTRA. Distinctly rounded, widest before middle of length (w/1 ratio: 0.79).

LEGS. Femora moderately clavate, armed with a distinct ventral tooth, tibiae straight. 
Genitalia. Body of penis elongate (w/1 ratio: 0.47$), 0.8 \times$ as long as apodemes, sides straight, subparallel, apex truncate, moderately and regularly curved in lateral view (Fig. 5P).

\section{Life history}

Unknown. The adults were collected in December in the Republic of South Africa and in November in Tanzania.

\section{Distribution}

Tanzania (Island of Zanzibar, Haran 2018), Republic of South Africa (Kwazulu-Natal Province).

\section{Remarks}

Smicronyx namibicus was wrongly described from Namibia due to a misinterpretation of the handwritten label of the holotype. The locality of this specimen is 'Zanzib' (Island of Zanzibar, Tanzania) and not 'Namib' (Namib Desert) as reported in Haran (2018). I thank Helene Perrin (MNHN) for highlighting this misreading.

\section{Key to Smicronychini of southern Africa}

1. Vestiture of elytra consisting of imbricate scales, polygonal, shiny, completely concealing the integument; middle of 4th interstria generally with a band of white scales (Fig. 1A). Body of penis very elongate (ratio w/l: 0.15), bearing erect setae laterally (Fig. 5A) .......Sharpia madibai sp. nov.

- Vestiture of elytra different, not combining these traits, lacking contrasting band of white scales on $4^{\text {th }}$ interstria. Body of penis shorter (ratio w/l above 0.20 ), sides smooth, not bearing erect setae. .2

2. Protibiae with a distinct tooth or thickening near middle of ventral side. Body size generally over $2.5 \mathrm{~mm}$ 3 (genus Afrosmicronyx Hustache, 1935)

- Ventral side of protibiae straight or slightly bisinuate, lacking tooth or thickening near middle of length. Body size equal to or under $2.5 \mathrm{~mm}$ 6 (genus Smicronyx Schönherr, 1843)

3. Body black; scales black, short, not overlapping on elytra (Fig. 1B)

A. cycnii sp. nov.

- Body covered with grey or brown or whitish scales, overlapping on elytra and concealing the integument

4. Antennae slender, segments 3-4 of funicle longer than wide. Tarsi elongate, the length of article 4 exceeding 3 , as long as the length of $1+2$ A. nebulosipennis sp. nov.

- Antennae more robust, segment 3-4 of funicle wider than long. Tarsi shorter, length of article 4 exceeding 3 , shorter than the length of $1+2$

5. Sides of body of penis straight (Fig. 5C), length longer (ration w/l: 0.36 ) A. louwi sp. nov.

- Sides of body of penis convex (Fig. 5D), length short (ration w/l: 0.56 ) A. marshalli sp. nov.

6. Integument dark red or with some shade of reddish. Vestiture of elytra forming a large transverse white band on apical half (Fig. 2E); scales rounded, as long as wide. Rostrum very distinctly downcurved in lateral view

S. zonatus Haran, 2018

- Integument of elytra of mature specimens at least partly black. Vestiture forming multiple, poorlydefined and narrow transverse whitish stripes, or vestiture homogenous or almost glabrous. Rostrum moderately downcurved in lateral view (Fig. 3D-E)

7. Body size over $2.2 \mathrm{~mm}$ 8

- Body size under $2.2 \mathrm{~mm}$ 
8. Integument of prothorax smooth. Scales on elytra elliptical, not overlapping ..S. gracilipes sp. nov.

- Integument of prothorax densely granulate. Scales on elytra rounded, isodiametric, overlapping ....

S. similis sp. nov.

9. Body of penis very short, isodiametric or slightly longer than wide in dorsal view (ratio w/1: 0.81), the sclerotized part of dorsal face narrowed longitudinally (Fig. 5L-M). Mesanepisterna and Metanepisterna densely covered with overlapping, rounded, whitish scales.

- Body of penis distinctly longer than wide (ratio w/ $<0.6$ ), dorsal face fully sclerotized (Fig. 5G-K, $\mathrm{N}-\mathrm{P}$ ). Episterna with brown or grey scales, generally not concealing the integument.

10. Prothorax strongly granulate, isodiametric (ratio w/1: 1). Elytra with white and brown scales forming ill-defined transverse white bands (Fig. 2A-C). Body of penis very short (ratio w/l: 1; Fig. 5L)

S. san sp. nov.

- Prothorax with coarse punctures, slightly longer than wide (ratio w/l: 1.07). Elytra with homogeneous cover of greyish scales, not forming particular pattern (Fig. 2D). Body of penis more elongate (ratio w/l: 0.60; Fig. 5M)

S. drakensbergensis sp. nov.

11. Scales on elytra of fresh specimens scarce, leaving large glabrous areas (Fig. 1H-I) 12

- Scales on elytra of fresh specimens forming a more or less dense cover over dorsal surface (Figs $1 \mathrm{~J}-$ $\mathrm{L}, 2 \mathrm{~F}-\mathrm{H})$ 13

12. Body of penis black, elongate (ratio w/1: 0.28; Fig. 5G), apodemes $1 / 4$ the length of the body. White scales on elytra generally forming transverse bands (Fig. 1H) S. pseudocoecus sp. nov.

- Body of penis brown, less elongate (ratio w/l: 0.44; Fig. 5H), apodemes as long as length of body. White scales on elytra very scarce, forming elliptical spots (Fig. 1I)

S. paucisquamis sp. nov.

13. Scales on elytra forming a contrasting black square on basal half of interstriae $1-4$, surrounded with white scales (Fig. 2H) S. namibicus Haran, 2018

- Pattern of elytra different 14

14. Pale scales on elytra generally condensed in an oblique band between shoulders and apical $2 / 3$ of suture of elytra (Figs 1J, 2G). Body of penis elongate (ratio w/1 $<0.35$ ) 15

- Pale scales on elytra forming multiple ill-defined transverse stripes or only condensed on shoulders. Body of penis shorter (ratio w/l $>0.40$ ) 16

15. Prothorax isodiametric (ratio w/l: 1). Claws always equal in length. Body of penis parallel sided in dorsal view, regularly thick in lateral view (Fig. 5I) S. fallax (Gyllenhal, 1836)

- Prothorax slightly wider than long (ratio w/l: 1.15). Claws generally unequal in length. Sides of body of penis slightly expanding toward apex in dorsal view ....S. albosquamosus Wollaston, 1854

16. Scales on elytra rounded, homogeneously brown with white scales condensed on shoulders and a few scattered on the rest of elytra (Fig. 2F). On Parthenium L. sp. S. lutulentus Dietz, 1894

- Scales on elytra elongate, much longer than wide, brown, grey or white, the pale scales forming illdefined transverse bands (Fig. 1K-L)

17. Integument of elytra at least partly reddish (Fig. 1L). Endophallus slightly sclerified, not visible at base of body of penis in dorsal view S. pauperculus Wollaston, 1864

- Integument of elytra entirely black (Fig. 1K). Endophallus sclerified, forming elongated striae at base of body of penis in dorsal view S. australis sp. nov. 


\section{Discussion}

This study enabled the recognition of 18 species of Smicronychini in southern Africa, of which 12 are described as new. The genera Sharpia and Afrosmicronyx are reported for the first time from this area. Southern African Smicronychini contain some typical tropical African elements (Genus Afrosmicronyx; species allied to Smicronyx guineanus) in its northern and central parts (northeastern South Africa, Zimbabwe). It also includes some widely distributed elements across the whole of Africa and the Mediterranean area (S. albosquamosus, S. pauperculus). Several species endemic to southern Africa are morphologically and molecularly closely related to West Palearctic species: $S$. jungermanniae and S. fallax; S. pauperculus and S. australis sp. nov.; S. coecus and S. pseudocoecus sp. nov. These pairs of species suggest a somewhat recent contact zone and then an allopatric speciation between these regions, as has been shown in several groups of organisms, including in plants and weevils (Hernández-Vera et al. 2013; Pirie et al. 2016).

The plant associations reported in this study are consistent with the known host families of Smicronychini in the old world: Gentianaceae, Convolvulaceae and Orobanchaceae (Caldara et al. 2014; Dieckmann 1990). However, the following genera are newly reported: Cycnium (Orobanchaceae), Chironia, Orphium and Sebaea (Gentianaceae). Several species of Smicronyx were found on the introduced dodder Cuscuta campestris and can be considered as candidate species for its biocontrol. Apart from this species, most Cuscuta of southern Africa are rare and red-listed species that do not threaten crops.

\section{Acknowledgments}

I wish to thank Robert Anderson (CMNC), Max Barclay (BMNH), Johannes Bergsten (NHRS), Roman Borovec (FFWS), Lourdes Chamorro (NMNH), Enzo Colonnelli, Roberto Casalini (MCZ), Madougou Garba (DGPVN, Niger), Elizabeth Grobbelaar, Riaan Stals (SANC), Ruth Müller (TMSA), Hélène Perrin (MNHN) and Simon van Noort (SAMC) for providing access to collections and for the loan of specimens that made this study possible. I thank Stuart Hall (Stellenbosch Botanical Garden, Republic of South Africa) for his help with the location and identification of plant associations for Smicronyx. I also thank Paula Strauss, Gary Beukman and Michael Lutzeyer for access to the Grootbos Private Nature Reserve and their friendly assistance during sampling and Laure Benoit (CIRAD) who assisted with the production of Barcode sequences. The following services are acknowledged for providing permits for insect sampling: Western Cape Province (Western Cape Nature Conservation Board [permit No. CN44-30-4229] and the Cape Research Centre [Republic of South African National Parks, CRC/20192020/012--2012/V1]); KwaZulu-Natal Province (Ezemvelo KZN Wildlife permits office, Collecting Permit KZN: OP1382-2019); Namibia (Collecting and MET delivered by Gobabeb in the course of the International Diptera Conference IDC9-2018). Finally, I acknowledge the collections platform of the CBGP (Emmanuelle Artige) for access to collections and imaging systems and Peter Biggins (CIRAD) who reviewed the English.

\section{References}

Anderson D.M. 1962. The Weevil Genus Smicronyx in America North of Mexico (Coleoptera: Curculionidae). Proceedings of the United States National Museum 113 (3456): 185-372. https://doi.org/10.5479/si.00963801.113-3456.185

Anderson D.M. 1974. Some species of Smicronyx (Coleoptera: Curculionidae) associated with Cuscuta (Convolvulaceae) in Pakistan. Proceedings of the Entomological Society of Washington 76: 359-374.

Anderson D.M. \& Cox M.L. 1997. Smicronyx species (Coleoptera: Curculionidae), economically important seed predators of witchweeds (Striga spp.) (Scrophulariaceae) in sub-Saharan Africa. Bulletin of Entomological Research 87 (1): 3-17. https://doi.org/10.1017/S0007485300036300 
Borovec R. \& Skuhrovec J. 2018. Afromuelleria, a new genus of Trachyphloeini from Limpopo, with descriptions of four new species (Coleoptera: Curculionidae: Entiminae). European Journal of Entomology 115: 668-683. https://doi.org/10.14411/eje.2018.066

Caldara R. 1989. Revisione tassonomica dei Tychius della Regione etiopica (Coleoptera Curculionidae). Atti della Società Italiana di Scienze Naturali e del Museo civico di Storia Naturale di Milano 130: $5-56$.

Caldara R. 1996. Description of ten new Afrotropical species of genus Tychius Germar, 1817 (Insecta: Coleoptera: Curculionidae: Tychiinae). Entomologische Abhandlungen 57: 213-224.

Caldara R. 2013. Curculioninae. In: Löbl I. \& Smetana A. (eds) Catalogue of Palaearctic Coleoptera. Vol. 8: 117-172. Brill, Leiden.

Caldara R., Colonnelli E. \& Osella G. 2009. On recently collected South African Tychiini and Mecinini, with description of seven new species. Fragmenta Entomologica 41 (1): 129-167.

Caldara R., Franz N.M. \& Oberprieler R.G. 2014. Curculioninae Latreille, 1802. In: Leschen R.A.B. \& Beutel R.G. (eds) Handbook of Zoology. Coleoptera, Beetles - Morphology and Systematics. Vol. 3: 589-628. De Gruyter, Berlin.

Dhileepan K., Madigan B., Vitelli M., McFadyen R., Webster K. \& Trevino M. 1996. A New initiative in the biological control of Parthenium. Eleventh Australian Weeds Conference Proceedings 11:309-3012.

Dieckmann L. 1990. Revision der Smicronyx reichi-Gruppe. Beiträge zur Entomologie 40 (2): 279-285.

Dietz W.G. 1894. Revision of the genera and species of Desmori of North America. Transactions of the American Entomological Society 21: 113-178.

Folmer O., Black M., Hoeh W., Lutz R. \& Vrijenhoek R. 1994. DNA primers for amplification of mitochondrial cytochrome c oxidase subunit I from diverse metazoan invertebrates. Molecular Marine Biology and Biotechnology 3 (5): 294-299.

Friedman L.A.L. 2017. The genus Sharpia Tournier in Israel (Coleoptera: Curculionidae, Curculioninae). Israel Journal of Entomology 47: 159-172.

Gyllenhal L. 1836 [new taxa]. In: Schoenherr C.J. (ed.) Genera et species curculionidum, cum synonymia hujus familice. Species nov. aut hactenus minus congnitce, descriptionibus a Dom. Leonardo Gyllenhal, C. H. Boheman, et entomologis aliis illustratce. Tomus tertius. - Pars secunda: 507-858. Roret, Fleischer, Parisiis / Lipsiæ.

Haran J. 2018. A review of the genus Smicronyx Schoenherr (Coleoptera, Curculionidae, Curculioninae) in tropical Africa. Zootaxa 4508 (2): 267-287. https://doi.org/10.11646/zootaxa.4508.2.9

Haran J. \& Perrin H. 2017. Revision of the genus Afrosmicronyx Hustache (Coleoptera, Curculionidae, Curculioninae). Zootaxa 4365 (2): 132-148. https://doi.org/10.11646/zootaxa.4365.2.2

Haran J., Schutte A. \& Friedman L.A.L. 2017. A review of Smicronyx Schöenherr (Coleoptera, Curculionidae) of Israel, with description of two new species. Zootaxa 4237 (1): 17-40.

https://doi.org/10.11646/zootaxa.4237.1.2

Haran J., Koutroumpa F., Magnoux E., Roques A. \& Roux G. 2015. Ghost mtDNA haplotypes generated by fortuitous NUMTs can deeply disturb infra-specific genetic diversity and phylogeographic pattern. Journal of Zoological Systematics and Evolutionary Research 53: 109-115.

Hernández-Vera G., Caldara R., Toševski I. \& Emerson B.C. 2013. Molecular phylogenetic analysis of archival tissue reveals the origin of a disjunct southern African-Palaearctic weevil radiation. Journal of Biogeography 40: 1348-1359. 
ICZN 1999. International Code of Zoological Nomenclature. $4^{\text {th }}$ Edition. The International Trust for Zoological Nomenclature. London, UK. Available from http://iczn.org [accessed March 2019].

Kumar S., Stecher G., \& Tamura K. 2016. MEGA7: Molecular Evolutionary Genetics Analysis version 7.0 for bigger datasets. Molecular Biology and Evolution 33: 1870-1874.

Louw S. 1995. Systematics and biogeography of the subfamily Microcerinae (Coleoptera: Curculionidae): A re-evaluation based on larval morphology. Memoirs of the Entomological Society of Washington 14: $169-174$.

Lyal C.H.C. 2019. Glossary of Weevil Characters. International Weevil Community. Available from: http://weevil.info/glossary-weevil-characters [accessed 15 Jul. 2019].

Marshall G.A.K. 1946. XXXII. - New South African Curculionidæ (Col.). Journal of Natural History. Series 11 (13): 249-263. https://doi.org/10.1080/00222934608654551

Péricart J. 1957. Contribution à l'étude du Genre Smicronyx (Subgen. Smicronyx s. str.) - Révision des especes gallo-rhénanes et corses (Col. Curculionidae). Annales de la Société entomologique de France 126: 71-89.

Pirie M.D., Olivier E.G.H., Mugrabi de Kuppler A., Gehrke B., Le Maitre N.C., Kandziora M. \& Bellstedt D.U. 2016. The biodiversity hotspot as evolutionary hot-bed: spectacular radiation of Erica in the Cape Floristic Region. BMC Evolutionary Biology 16 (190).

https://doi.org/10.1186/s12862-016-0764-3

Proches S. 2003. Every plant has its weevil. Veld and Flora 89: 118-120.

Schoenherr C.J. 1843. Genera et species curculionidum, cum synonymia hujus familice. Species nov. aut hactenus minus congnite, descriptionibus a Dom. Leonardo Gyllenhal, C. H. Boheman, et entomologis aliis illustratce. Tomus septimus. - Pars secunda: 1-461. Roret, Fleischer, Parisiis / Lipsiæ.

Strathie L.W., McConnachie A.J. \& Retief E. 2011. Initiation of Biological Control Against Parthenium hysterophorus L. (Asteraceae) in South Africa. African Entomology 19 (2): 378-392.

Wollaston T.V. 1854. Insecta Maderensia, Being an Account of the Insects Inhabiting the Islands of the Madeiran Group. xliii. J. van Voorst, London. https://doi.org/10.5962/bhl.title.9060

Wollaston T.V. 1864. Catalogue of the Coleopterous Insects of the Canaries in the Collection of the British Museum. xii. J. van Voorst, London. https://doi.org/10.5962/bhl.title.9850

Zumpt F. 1936. Curculioniden-Studien XIV. Revision der palaearktischen Arten der Gattung Sharpia Tourn. Memorie della Società Entomologica Italiana 15: 25-36.

Manuscript received: 19 November 2019

Manuscript accepted: 26 November 2020

Published on: 17 February 2021

Topic editor: Nesrine Akkari

Section editor: Max Barclay

Desk editor: Eva-Maria Levermann

Printed versions of all papers are also deposited in the libraries of the institutes that are members of the EJT consortium: Muséum national d'histoire naturelle, Paris, France; Meise Botanic Garden, Belgium; Royal Museum for Central Africa, Tervuren, Belgium; Royal Belgian Institute of Natural Sciences, Brussels, Belgium; Natural History Museum of Denmark, Copenhagen, Denmark; Naturalis 
HARAN J.M., Review of southern African Smicronychini (Coleoptera, Curculionidae)

Biodiversity Center, Leiden, the Netherlands; Museo Nacional de Ciencias Naturales-CSIC, Madrid, Spain; Real Jardín Botánico de Madrid CSIC, Spain; Zoological Research Museum Alexander Koenig, Bonn, Germany; National Museum, Prague, Czech Republic. 